\title{
Olig1 Function Is Required for Oligodendrocyte Differentiation in the Mouse Brain
}

\author{
Jinxiang Dai, Kathryn K. Bercury, Jared T. Ahrendsen, and Wendy B. Macklin \\ Department of Cell and Developmental Biology, University of Colorado School of Medicine, Aurora, Colorado 80045
}

Oligodendrocyte differentiation and myelination are tightly regulated processes orchestrated by a complex transcriptional network. Two bHLH transcription factors in this network, Olig1 and Olig2, are expressed exclusively by oligodendrocytes after late embryonic development. Although the role of Olig2 in the lineage is well established, the role of Olig1 is still unclear. The current studies analyzed the function of Olig1 in oligodendrocyte differentiation and developmental myelination in brain. Both oligodendrocyte progenitor cell commitment and oligodendrocyte differentiation were impaired in the corpus callosum of Olig1-null mice, resulting in hypomyelination throughout adulthood in the brain. As seen in previous studies with this mouse line, although there was an early myelination deficit in the spinal cord, essentially full recovery with normal spinal cord myelination was seen. Intriguingly, this regional difference may be partially attributed to compensatory upregulation of Olig2 protein expression in the spinal cord after Olig1 deletion, which is not seen in brain. The current study demonstrates a unique role for Olig1 in promoting oligodendrocyte progenitor cell commitment, differentiation, and subsequent myelination primarily in brain, but not spinal cord.

Key words: CNS; myelination; Olig1

\section{Introduction}

Myelin ensheathment of axons dramatically increases axonal conduction velocity and provides valuable trophic support to axons (Bullock et al., 1984; Hildebrand et al., 1993; Nave, 2010). In demyelinating diseases, such as multiple sclerosis (MS), remyelination occurs, but the myelin is thinner than normal and many axons remain demyelinated (Franklin and Ffrench-Constant, 2008). Oligodendrocyte progenitor cells (OPCs) and premyelinating cells are present in MS lesions, but in general, remyelination is greatly impaired in MS tissue (Chang et al., 2000, 2002; Kuhlmann et al., 2008). Thus, understanding the molecular mechanisms driving oligodendrocyte maturation and myelination remains an extremely important research question.

Over the past decade, much of the transcriptional regulatory network of oligodendrocyte lineage progression has been elucidated (Emery, 2010a). Two transcription factors, Olig1 and Olig2, are closely related basic helix-loop-helix (bHLH) transcription factors that play critical roles in oligodendrocyte specification and differentiation (Lu et al., 2002; Zhou and Anderson, 2002). Although it appears to have an essential role in remyelination (Arnett et al., 2004), the function of Olig1 during oligoden-

\footnotetext{
Received Dec. 5, 2014; revised Jan. 23, 2015; accepted Feb. 6, 2015.

Author contributions: J.D. and W.B.M. designed research; J.D. and K.K.B. performed research; J.D. and J.T.A. analyzed data; J.D., K.K.B., and W.B.M. wrote the paper.

This work was supported by NS08223 and an NRSA fellowship (J.T.A.).We thank Katherine E. Saul for technical assistance, Dorothy Dill for assistance with electron microscopy, and Marnie Preston for helpful discussion.

The authors declare no competing financial interests.

Correspondence should be addressed to Dr Wendy B. Macklin, Department of Cell and Developmental Biology University of Colorado School of Medicine, 12800 East $17^{\text {th }}$ Avenue, Building RC1S, Room L18-12403B, Aurora, CO 80045. E-mail: Wendy.Macklin@ucdenver.edu.

DOI:10.1523/JNEUROSCI.4962-14.2015

Copyright $\odot 2015$ the authors $\quad 0270-6474 / 15 / 354386-17 \$ 15.00 / 0$
}

drocyte development is still unclear. This results from the fact that several Olig1-null lines have been developed that have quite different phenotypes (Lu et al., 2002; Xin et al., 2005; Paes de Faria et al., 2014). Oligodendrocyte differentiation in developing spinal cord is delayed in the original Olig1-null mouse, yet there is no long-term developmental problem ( $\mathrm{Lu}$ et al., 2002). It was hypothesized that this mild phenotype might result from compensation by Olig2 (Lu et al., 2002), and a second Olig1-null mouse was designed to reduce any Olig2 compensation. This animal has greater dysmyelination and dies by postnatal day (P)14 (Xin et al., 2005). Two additional Olig1-null mouse lines were recently described, which were generated by different strategies, and only mild developmental delay of spinal cord myelination is found in these mice (Paes de Faria et al., 2014).

In ongoing studies using the original Olig1-Cre mice for gene deletion in oligodendrocytes, we noted unexpected changes in myelination in the brains of homozygous-null Olig1-Cre mice. In general, the studies on the different Olig1-null mouse lines have focused on spinal cord development. However, differential regulation of oligodendrocyte differentiation and myelination has been seen in different brain regions (Fruttiger et al., 1999; Sperber et al., 2001; Bercury et al., 2014; Wahl et al., 2014). We therefore began investigating the role of Olig1 in oligodendrocyte development outside the spinal cord. These studies demonstrate that in the brain, Olig1 has a critical role in the commitment of pre-OPCs to OPCs and for subsequent OPC differentiation. The data from the current study demonstrate a unique role of Olig1 in promoting OPC commitment and differentiation, which appears more important in brain than spinal cord OPCs. 

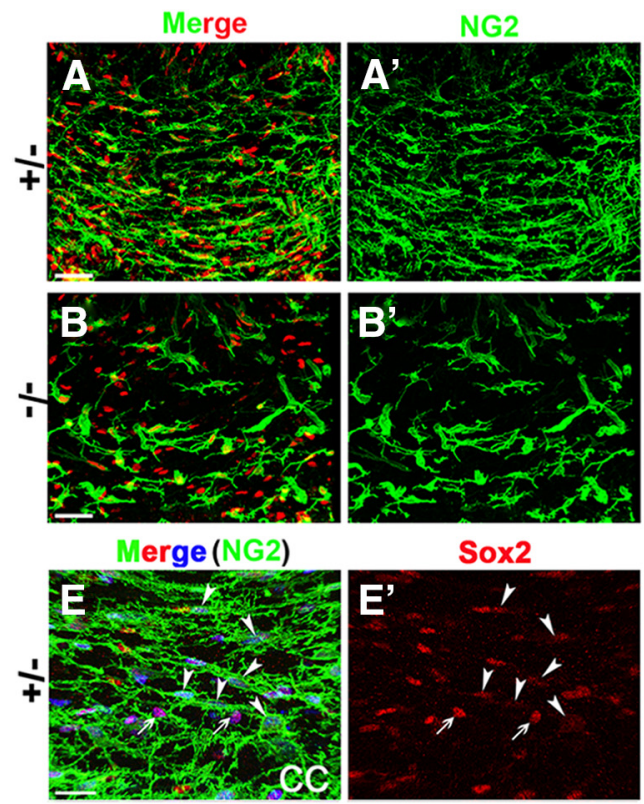

Sox2
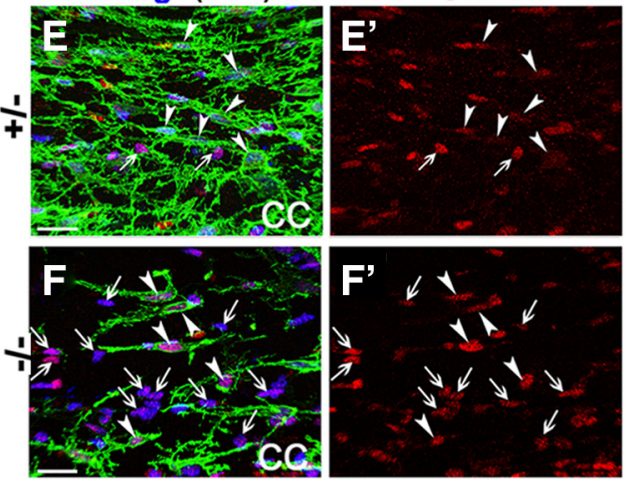
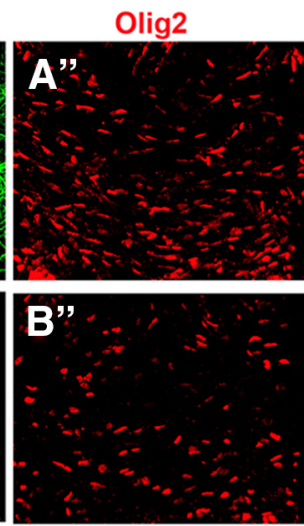

Olig2
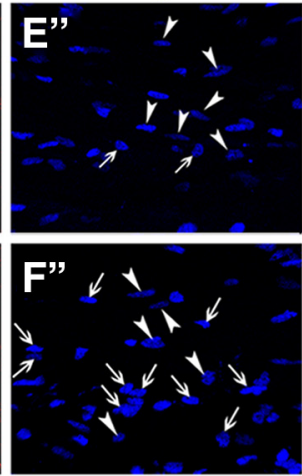
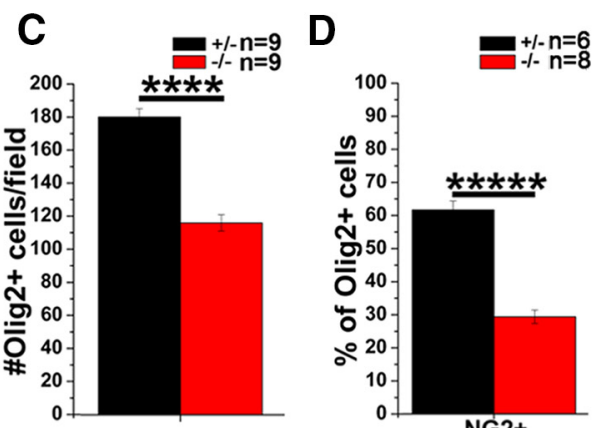

NG2+

Figure 1. Deficit of pre-OPC to OPC commitment in P1 Olig1-null mice. $A, B$, Representative images of cells stained with NG2 (green) and Olig2 (red) in the corpus callosum of P1 Olig1 heterozygous $\left(\boldsymbol{A}, \boldsymbol{A}^{\prime}, \boldsymbol{A}^{\prime \prime}\right)$ versus Olig1-null $\left(\boldsymbol{B}, \boldsymbol{B}^{\prime}, \boldsymbol{B}^{\prime \prime}\right)$ mice. Scale bar, $50 \mu \mathrm{m}$. $\boldsymbol{C}, \boldsymbol{D}$, Quantification of total Olig2 + cells $(\boldsymbol{C})$ and proportion of NG2 + cells within 0 lig2 + cells $(\boldsymbol{D})$. $\boldsymbol{E}, \boldsymbol{F}$, Representative images of cells stained with NG2 (green), Sox2 (red), and Olig2 (blue) in the corpus callosum of P1 Olig1 heterozygous $\left(\boldsymbol{F}, \boldsymbol{F}^{\prime}, \boldsymbol{F}^{\prime \prime}\right)$ versus Olig1-null $\left(\boldsymbol{G}, \boldsymbol{G}^{\prime}, \boldsymbol{G}^{\prime \prime}\right)$ mice. Arrows mark NG2-Sox2 ${ }^{\text {high }}$ 0lig2 + pre-OPCs and arrowheads mark the NG2 + Sox2 ${ }^{\text {low }} 0$ lig2 + OPCs. Scale bar, $50 \mu \mathrm{m}$. G, Quantification of the proportion of Sox2 + NG2- pre-OPC population within Olig2 + cells. H, Quantification of the total Sox2 + cells, and cells with high and low Sox2 staining, respectively. For all quantifications, data represent mean \pm SEM; the number of animals analyzed was indicated in each panel; ${ }^{* * * *} p<0.00005$, ${ }^{* * * *} p<0.000005$; unpaired Student's $t$ test).

\section{Materials and Methods}

Animals. The B6;129S4-Olig1tm1(cre)Rth/J strain of Olig1-null mice was obtained from The Jackson Laboratory (stock no. 011105). The original mixed background mouse strain has been backcrossed to C57BL/6 mice over numerous generations during the last 12 years. The total number of oligodendrocyte lineage cells and mature cells was quantified in Olig1 $^{+/-}$and wild-type mice at both P15 and 1 month of age and no differences were observed between them. Therefore, we used male and female Olig1 ${ }^{+1-}$ and Olig1 ${ }^{-1-}$ littermates for further analysis. Genotypes of all mice were determined by PCR analysis of tail genomic DNA based on the suggested Jackson Laboratory protocol with modified PCR primers. PCR primers specific for wild-type alleles were as follows: Olig1WT-F, 5'-AAACGCTGCGCCCCACCAAG-3', and Olig1-WT-R, 5' TCACTTGGAGAACTGGGCCT-3'; for mutant alleles, they were as follows: Olig1-Mut-F, 5' -CGCCCCAGATGTACTATGC-3', and Olig1Mut-R, 5'-AATCGCGAACATCTTCAGGT-3'. All animal procedures were performed in an AAALAC-accredited facility in accordance with the Guide for the Care and Use of Laboratory Animals and approved by the University of Colorado Denver Institutional Animal Care and Use Committee.

Immunohistochemistry, immunocytochemistry, and TUNEL assay. Mouse perfusion and immunohistochemistry was performed as described previously (Trapp et al., 1997), with some modifications. Freefloating cortex and cervical spinal cord sections $(30 \mu \mathrm{m})$ were analyzed, with antigen retrieval in $10 \mathrm{~mm}$ sodium citrate $(\mathrm{pH} 6.0)$ at $65^{\circ} \mathrm{C}$ for 10 min as needed, using a Pelco Biowave Pro tissue processor (Ted Pella). For immunocytochemistry, oligodendrocytes were cultured on coverslips (see Primary cell culture and electroporation, below) and fixed with $4 \%$ paraformaldehyde for $15 \mathrm{~min}$ at RT. Cells were permeabilized with $0.1 \%$ Triton X-100 for 10 min, blocked with 3\% BSA in PBS for 60 min at
$\mathrm{RT}$, and incubated with primary antibodies overnight at $4^{\circ} \mathrm{C}$. For detection of $\mathrm{O} 4$ cell surface antigens, $\mathrm{O} 4$ antibody was diluted with media and incubated with live cells on coverslips for $1 \mathrm{~h}$ before fixation.

Cell death was analyzed by TUNEL (terminal deoxynucleotidyl transferase-mediated dUTP nick end labeling) assay. Sections were permeabilized with 3\% Triton X-100 for $30 \mathrm{~min}$, and labeled with in situ cell death detection kit following the manufacturer's instructions (Roche Applied Science, no. 11684795910).

The following primary antibodies were used: guinea pig anti-NG2 (gift from Dr W. Stallcup, Burnham Institute, La Jolla, CA), rabbit anti-Olig2 and Olig1 (a gift from Dr Charles Stiles, Harvard University, Cambridge, MA), rat anti-PLP/DM20 (Clone AA3), O4 hybridoma (gift from Dr Rashmi Bansal, University of Connecticut Health Sciences Center, Farmington, CT), rat anti-BrdU (Accurate Chemical, no. YSRTMCA2060GA), rabbit anti-Sox2 (Millipore, no. ab5603), goat-anti-Sox2 (Santa Cruz Biotechnology, no. sc-17320), mouse antiOlig2 (Millipore, no. MABN50A4), rabbit anti-Ki67 (Abcam, no. 16667), mouse anti-CC1 (Millipore, no. OP80), goat anti-Sox10 (Santa Cruz Biotechnology, no. sc-17342), rabbit anti-PDGFR $\alpha$ (Santa Cruz Biotechnology, no. sc-338), chicken anti-neurofilament (Neuromics, no. CH22105), and rabbit anti-MBP (Millipore, no. ab980).

Primary cell culture and electroporation. Mouse neural progenitor cells were isolated from Olig1 heterozygous or null neocortex E12.5-E14.5 embryos to generate neurospheres and OPCs as previously described (Pedraza et al., 2008). Rat mixed glial cultures were generated from P0 to P3-d-old Sprague-Dawley rat pups as described previously (Dai et al., 2014). Oligodendrocyte cultures were typically $>90 \%$ pure as assessed by immunocytochemistry for the oligodendrocyte lineage markers PDGFR $\alpha /$ NG2 and Olig2 and the astrocytic marker glial fibrillary acid protein. Rat OPCs were shaken from mixed cultures after $10 \mathrm{~d}$ and $5 \times$ 

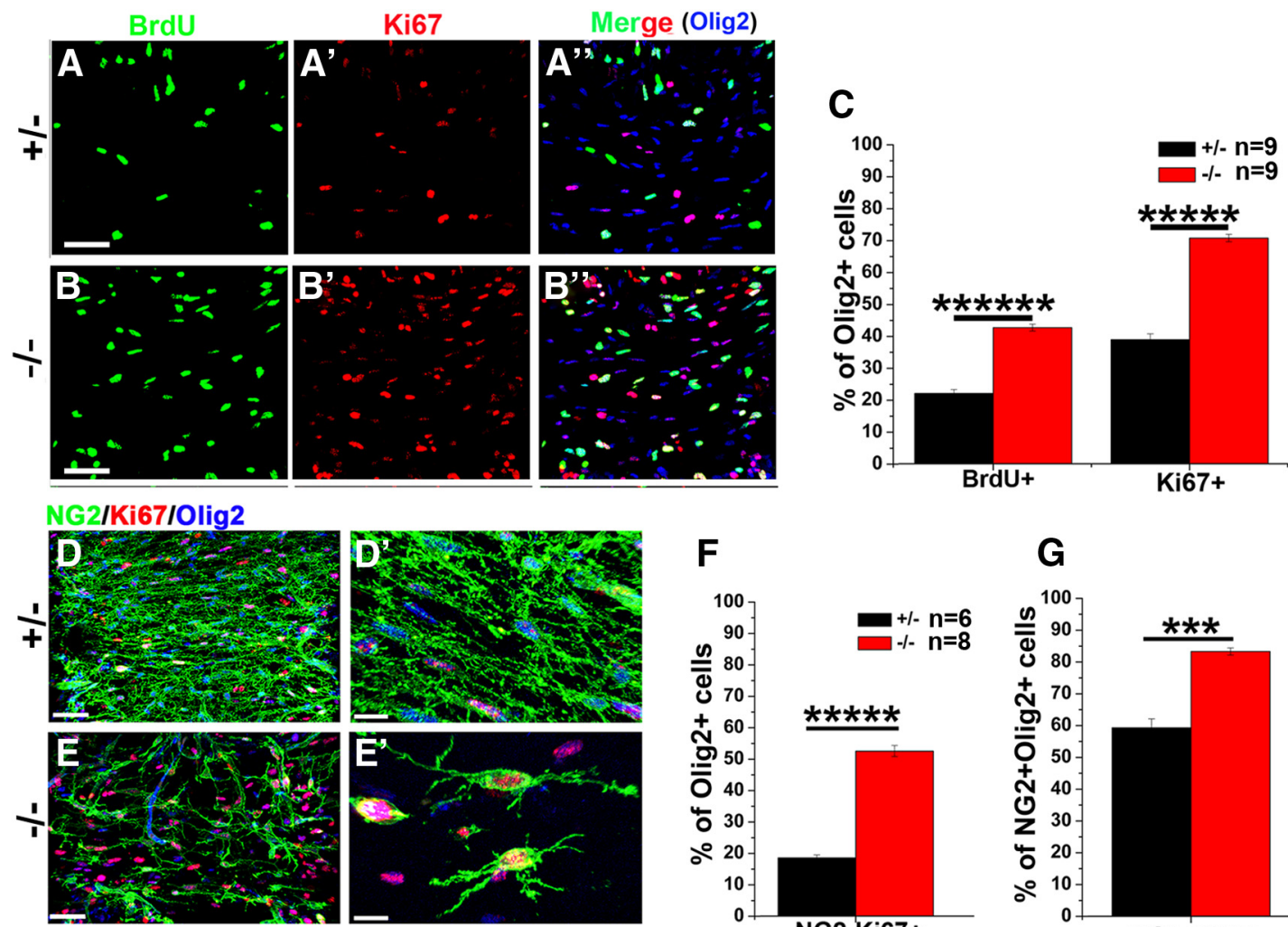

$\mathbf{F}$

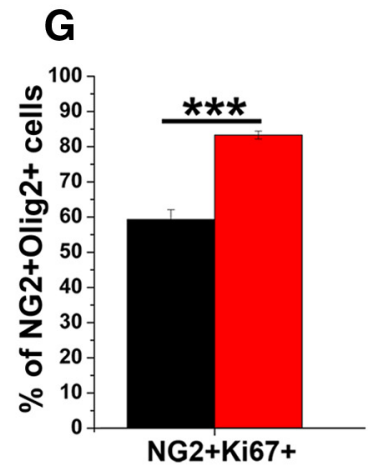

\section{TUNEL/Olig2}
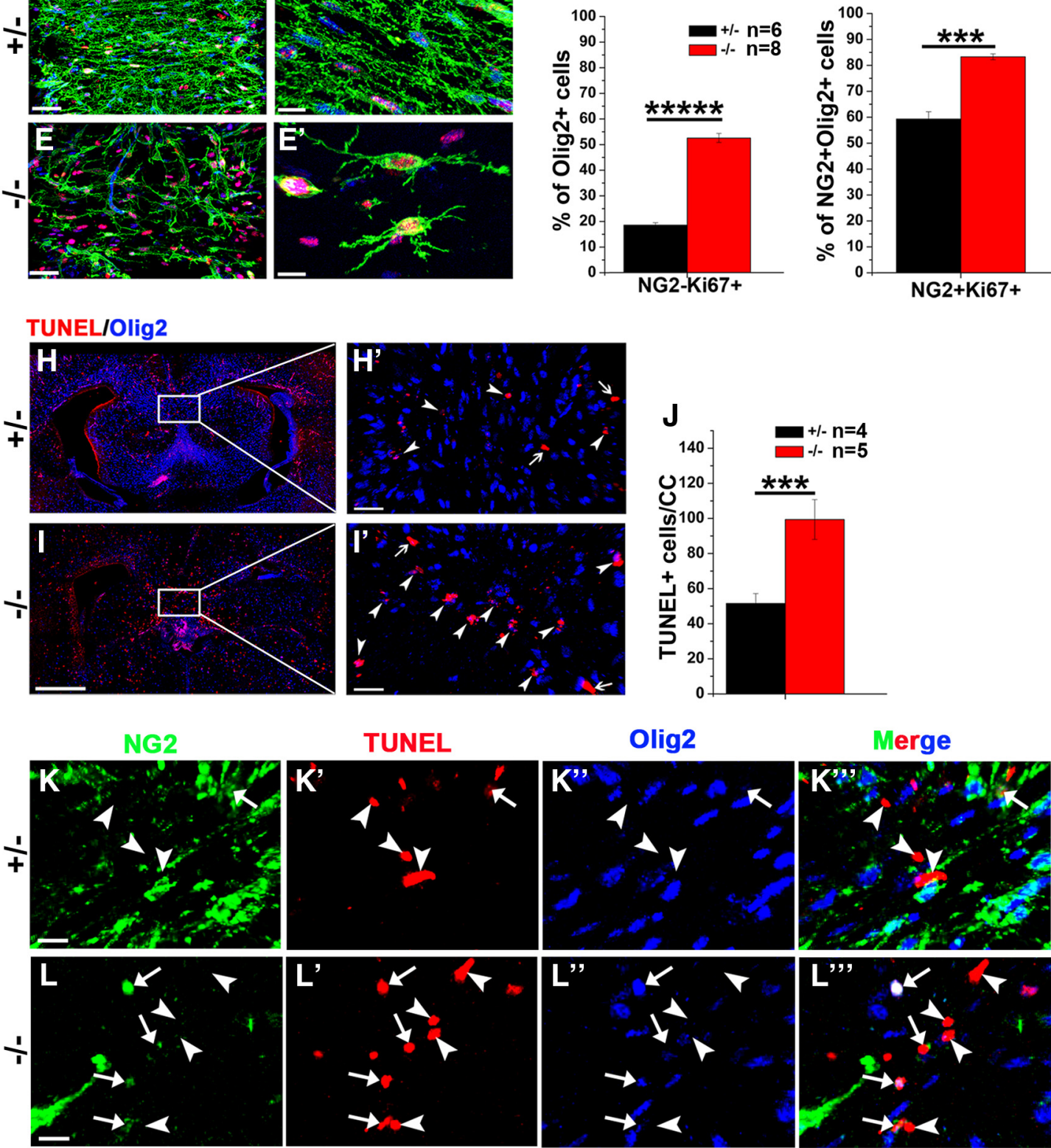

Figure 2. Enhanced progenitor cell proliferation and apoptosis in P1 Olig1-null mice. $\boldsymbol{A}, \boldsymbol{B}$, Representative images of the BrdU $+($ green; $A, B)$, Ki67 $+\left(\right.$ red; $\left.\boldsymbol{A}^{\prime}, \boldsymbol{B}^{\prime}\right)$ cells and merged with 0lig2 + $\left(A^{\prime \prime}, B^{\prime \prime}\right)$ cells in the subcortical white matter of P1 Olig1 heterozygous (A) or Olig1-null (B) mice pulse injected with BrdU for $2 \mathrm{~h}$. Scale bar, $50 \mu \mathrm{m}$. $C$, Quantification of the proportion of BrdU + and Ki67 + cells within the 0lig2 + OPC population. D, E, Representative images of cells stained with NG2 (green), Ki67 (red), and Olig2 (blue) in the corpus callosum of P1 Olig1 heterozygous (D) versus Olig1-null $(\boldsymbol{E})$ mice. High-magnification images $\left(\boldsymbol{D}^{\prime}, \boldsymbol{E}^{\prime}\right)$ highlight less complex OPC morphology in Olig1-null mice. Scale bars: $\boldsymbol{D}, \boldsymbol{E}, 50 \mu \mathrm{m} ; \boldsymbol{D}^{\prime}, \boldsymbol{E}^{\prime}, 15 \mu \mathrm{m} . \boldsymbol{F}, \boldsymbol{G},($ Figure legend continues.) 
$10^{6}$ cells were electroporated (Amaxa nucleofection apparatus, Lonza) in $100 \mu \mathrm{l}$ Nucleofection solution (Amaxa basic glial cells nucleofector kit, Lonza, no. VPI-1006, IL) with siRNAs ( $10 \mu \mathrm{l}$ of $20 \mu \mathrm{m}$ rat Olig1 siRNAs (no. L100044-01) or siControl nontargeting siRNA pool (no. B002000UB) from Dharmacon (Thermo Scientific). After electroporation, cells were resuspended and seeded onto poly-D-lysine/laminin-coated dishes or round $12 \mathrm{~mm}$ coverslips in DMEM supplemented with N2 (Life Technologies, no. 17502-048), Fibroblast growth factor (FGF, $10 \mathrm{ng} / \mathrm{ml}$ ) and Platelet-derived growth factor (PDGF, $10 \mathrm{ng} / \mathrm{ml}$ ) for $24 \mathrm{~h}$, after which they were incubated in differentiation media for $1 \mathrm{~d}$.

Cell counts and immunofluorescence quantification. For oligodendrocyte lineage cell number quantification of Olig1 mutant mice, images at $40 \times$ magnification were obtained either at the midline of the corpus callosum or in the dorsal column of the cervical spinal cord on a Leica SP5 confocal microscope. Cells within the field of each image for the corpus callosum or spinal cord were counted with the ImageJ cell counting plugin. Three sections per animal were quantified from at least five animals per group. To quantify the fluorescence intensity of proteolipid protein (PLP) and myelin basic protein (MBP) immunoreactivity in corpus callosum, the corrected total cell fluorescence (CTCF) was calculated as the Integrated Density-(Area of selected cell $\times$ mean fluorescence of background readings; Burgess et al., 2010). For cultured primary oligodendrocytes, images were taken on a Zeiss Axio Imager M2. A total of six microscopic fields per coverslip with two coverslips per condition were sampled in each experiment. The total number of cells counted per condition averaged 700-1500. The total branch points/cell of O4+ cells was analyzed with Imaris filament tracer module (Bitplane).

Western blot. Cultured cells, brain or spinal cord tissue were lysed in RIPA buffer (25 mm Tris-HCl, pH 7.5, $150 \mathrm{~mm} \mathrm{NaCl}, 1$ mм EDTA, $1 \%$ NP-40, $0.1 \%$ SDS, $0.1 \%$ DOC) supplemented with complete miniprotease inhibitor cocktail (Roche Applied Science) and phosphatase inhibitor cocktail set II (Calbiochem, no. 564652). Samples were analyzed by a standard Western blot protocol. Protein bands were detected using the LICOR Odyssey infrared scanner (LI-COR Bioscience) and proteins were quantified using the Odyssey Scanner Software 2.0. The following primary antibodies were used: rabbit anti-myelin associated glycoprotein (MAG; Cell Signaling Technology, no. 8043), rabbit anti2',3'-cyclic-nucleotide 3'-phosphodiesterase (CNPase; Cell Signaling Technology, no. 5664), rabbit anti-myelin oligodendrocyte glycoprotein (MOG; Abcam, no. 32760), mouse anti-MBP (Covance, no. SMI-94), mouse anti- $\beta$-tubulin (Sigma-Aldrich, no.T8328), rabbit anti-glyceraldhyde-3-phosphate dehydrogenase (Cell Signaling Technology, no. 2118). Samples were loaded at $50 \mu \mathrm{g}$ protein/lane to detect myelin proteins in P15 cerebral samples and at $20 \mu \mathrm{g} /$ lane for others. To detect Olig 1 and Olig2, $100 \mu \mathrm{g}$ protein/lane was loaded.

Electron microscopy. Animals were perfused with cold PBS followed by modified Karnovsky's fixative (2\% paraformaldehyde/2.5\% glutaraldehyde). The brain and spinal cord were removed and postfixed overnight in the same fixative. Corpus callosum was isolated from $1 \mathrm{~mm}$ coronal slices of brain between -0.94 and -2.18 of bregma. All tissue was postfixed in $1 \%$ osmium tetroxide, dehydrated in graded acetone, and resin embedded in Embed 812 (Electron Microscopy Sciences) using a Pelco Biowave Pro tissue processor (Ted Pella). The corpus callosum samples

$\leftarrow$

(Figure legend continued.) Quantification of the proportion of NG2-/Ki67 + pre-OPCs within the Olig2 + cells $(\boldsymbol{F})$ and NG2 +/Ki67 + proliferating OPCs within the NG2 + OPC population (G). $\boldsymbol{H}, \mathbf{I}$, Low-magnification images of the cerebrum stained with TUNEL (red) and Olig2 (blue) of the P1 Olig1 heterozygous $(\boldsymbol{H})$ versus Olig1-null $(\boldsymbol{I})$ mice. $\boldsymbol{H}^{\prime}, \boldsymbol{I} \boldsymbol{I}^{\prime}$, High-magnification images of the corpus callosum corresponding to the box insets in panel $(\boldsymbol{H})$ and $(\boldsymbol{I})$. Arrows mark TUNEL + I Olig2- cells and arrowheads mark the TUNEL + /Olig2 + dying OPCs. Scale bars: $\boldsymbol{H}, \boldsymbol{I}, 500 \mu \mathrm{m}$; $\boldsymbol{H}^{\prime}, \boldsymbol{I}^{\prime}, 50 \mu \mathrm{m}$. J, Quantification of TUNEL + cells at the midline of corpus callosum in Olig1 heterozygous versus Olig1-null mice. $\boldsymbol{K}, \boldsymbol{L}$, Representative images of cells stained with NG2 (green), TUNEL (red), and Olig2 (blue) within the corpus callosum of control (K) versus Olig1null ( $L$ ) mice. Arrows mark TUNEL +/NG2 + cells; arrowheads mark the TUNEL +/NG2- cells. Scale bar, $10 \mu \mathrm{m}$. For all quantifications, data represent mean $\pm S E M$; the number of animals analyzed was indicated in each panel; ${ }^{* * *} p<0.0005,{ }^{* * * *} p<0.000005,{ }^{* * * * * *} p<$ 0.0000005; unpaired Student's $t$ test). were oriented such that sections could be cut midline in a sagittal plane. Ultrathin sections $(80 \mathrm{~nm}$ ) were mounted on copper grids, stained with uranyl acetate and lead citrate, and viewed at $80 \mathrm{kV}$ on a Technai G2 transmission electron microscope (FEI). Electron micrographs of the corpus callosum were imaged at midline.

Statistical analysis. For cell counts, the mean number of immunoreactive cells per image field was determined. Student's $t$ test, paired or unpaired, was used to calculate statistical significance and graphed using OriginPro (Origin lab) or Graphpad Prism. Values represent the mean \pm SEM.

\section{Results \\ OPC production, differentiation, and early morphogenesis were reduced in Olig1-null mice}

The impact of Olig1 on OPC specification and number in the corpus callosum during the early postnatal period was investigated. In Olig1-null mice at $\mathrm{P} 1$, there was a $40 \%$ reduction in the total number of oligodendrocyte lineage cells (Olig2+) in subcortical white matter compared with control (Fig. $1 A-C$ ). This reduction is consistent with a recent study that showed reduced oligodendrocyte lineage cells in Olig1-null mice and ectopic production of interneurons (Silbereis et al., 2014). Within the Olig2 + cell population in the Olig1-null mice, the percentage that were NG2 + OPCs was only approximately half that in control animals (Fig. $1 A, B, D$ ). Thus, compared with control P1 animals, where $61.9 \%$ of Olig2 + cells are $\mathrm{NG} 2+$, intriguingly, in the Olig1-null mice, only $29.5 \%$ of the Olig2 + cells were also $\mathrm{NG} 2+$ (Fig. 1D). To identify the Olig2 +/NG2 - cell population, we analyzed expression of a pre-OPC marker, Sox2. Sox2 is expressed in the subventricular zone (SVZ) by neural progenitors and by pre-OPCs (Olig2+/Sox2+ cells) migrating out of the SVZ (Ellis et al., 2004; Menn et al., 2006; Hu et al., 2009b; Wang et al., 2013). Once pre-OPCs reached the subcortical white matter, they reduced Sox 2 expression and transitioned into Olig2+/NG2+ OPCs (Fig. 1E,F). At P1, this reduction in Sox 2 expression was still in progress. Thus, there were cells with high Sox 2 expression, presumably pre-OPCs, and cells with low Sox2, presumably cells beginning to differentiate to OPCs. The total number of Sox2+ cells was reduced in Olig1-null mice (Fig. 1G), which may reflect the reduction in total oligodendrocyte lineage cells in Olig1-null mice that occurs at early specification stages (Silbereis et al., 2014). The pre-OPC population was quantified as the number of Olig2+/Sox2+/NG2 - cells in control or Olig1-null mice, including both high and low-expressing Sox $2+$ cells. Interestingly, there was a significant increase in the percentage of Olig2 + cells that were Olig2+/Sox2+/NG2- pre-OPCs in Olig1-null mice, relative to control mice (Fig. $1 G$ ). Furthermore, as can be seen in Figure $1 E, F$, whereas Sox2 levels were very low in NG2+ cells in control samples (Fig. $1 E, H$, merged image; $E^{\prime}$, Sox 2 image, compare arrowheads to arrows), in Olig1-null cells, numerous NG2+ cells retained strong Sox 2 stain (Fig. 1 F, H, merged image, arrowheads). This apparent delay/deficit in the downregulation of Sox2 and the transition from pre-OPC to OPC in Olig1-null mice suggest an important role of Olig1 in this very early stage of oligodendrocyte development, a stage that has not been investigated extensively in vivo previously.

Despite being a smaller population, the Olig2 + cells in Olig1 null mice were highly proliferative (Fig. $2 A, B$ ). P1 pups were injected with BrdU and killed $2 \mathrm{~h}$ later; tissue was analyzed for BrdU incorporation coupled with Ki67 immunohistochemistry. BrdU permanently labels cells during $S$ phase, and their progeny retain the label, whereas Ki67 is a marker of proliferating cells currently in cell cycle (Kee et al., 2002). The number of Olig2+ cells that were either BrdU+ or $\mathrm{Ki} 67+$ was quantified in the 

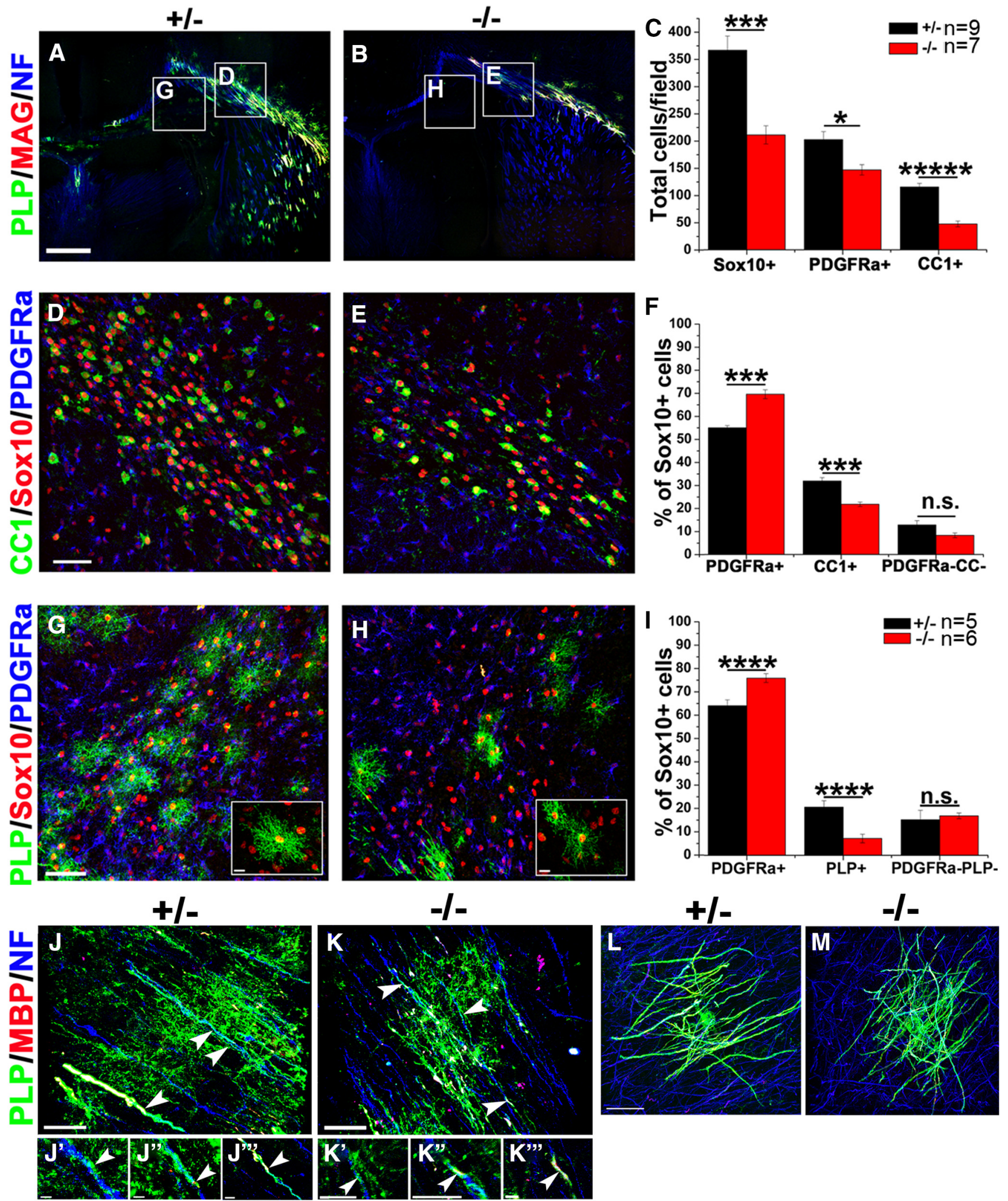

Figure 3. Oligodendrocyte differentiation and myelination initiation in P8 Olig1-null mice. $\boldsymbol{A}, \boldsymbol{B}$, Low-magnification images of cerebrum of Olig1 heterozygous $(\boldsymbol{A})$ versus 0 lig1-null $(\boldsymbol{B})$ at $\mathrm{P8}$ stained for PLP (green), MAG (red), and neurofilament protein(blue), indicating impaired myelination initiation both in corpus callosum and striatum. Scale bar, $400 \mu \mathrm{m}$. C, Quantification of total number of oligodendrocyte lineage cells (Sox10+), OPCs (PDGFR $\alpha+$ ), or mature oligodendrocytes $(C C 1+$ ) as shown in $\boldsymbol{D}$ and $\boldsymbol{E}$. D, $\boldsymbol{E}$, Representative image showing reduced mature oligodendrocytes $(C(C 1+)$ in P8 Olig1-null brain (E) relative to control (D), corresponding to region of the insets labeled D and E, in $\boldsymbol{A}$ and $\boldsymbol{B}$, respectively. Scale bar, $50 \mu \mathrm{m}$. $\boldsymbol{F}$, Quantification of the percentage of Sox $10+$ cells that are OPCS (PDGFR $\alpha+$ ), mature oligodendrocytes(CC $1+$ ), and immature oligodendrocytes (PDGFRa $-/ C C 1-$ ) as shown in $\boldsymbol{D}$ and $\boldsymbol{E}$ in lateral corpus callosum of Olig1 heterozygous versus Olig1-null mice, demonstrating a blockage of oligodendrocyte differentiation in Olig1-null mice. $\boldsymbol{G}, \boldsymbol{H}$, Representative images showing fewer premyelinating oligodendrocytes with bushy morphology (PLP+) in Olig1-null mouse corpus callosum. Scale bar, $50 \mu \mathrm{m}$; insets, $10 \mu \mathrm{m}$. I, Quantification of percentage of OPCS (PDGFR $\alpha+$ ), premyelinating oligodendrocytes $(\mathrm{PLP}+$ ) and immature oligodendrocytes (PDGFR $\alpha-\mathrm{PLP}-$ ) as shown in $\mathbf{G}$ and $\boldsymbol{H} . \boldsymbol{J}, \boldsymbol{K}$, High-magnification image of myelinating oligodendrocytes(PLP+; green) from (Figure legend continues.) 
subcortical white matter. The percentage of Olig2 + cells that were BrdU + or Ki67 + in P1 Olig1-null mice was essentially twice that of control (Fig. $2 C$ ). Both the pre-OPCs (Olig2+/NG2-) and the OPCs (Olig2+/NG2+) had far more Ki67 expression $(52.7 \%$ and $83.2 \%$, respectively) than control cells (18.6\% and $59.2 \%$ respectively; Fig. $2 D-G$ ). These data suggested that a significant segment of the Olig2 + cell population remained in the cell cycle in Olig1-null mice at P1.

Despite their increased proliferation, the number of Olig2+ cells remained lower in Olig1-null mice, and it seemed possible that the reduced number of cells resulted from increased cell death (Reid et al., 1999; Castedo et al., 2004). Indeed, cell death essentially doubled in the Olig1-null mice (Fig. $2 \mathrm{H}-J$ ). Although many dying cells had lost their cell-specific markers, a number of these apoptotic cells in Olig1-null mice expressed NG2 proteoglycan, which was only rarely seen in control mice (Fig. $2 K, L$, arrows). Thus, the increased cell death in Olig1-null mice was likely in OPCs that failed to differentiate properly. These data indicate that OPCs were delayed in exiting cell cycle in Olig1-null mice, and the number of both proliferative (Ki67+) and dying cells (TUNEL +) in the Olig1-null mice was twice that in control mice. Thus, it appears that in the absence of Olig1, Olig2 + cells failed to effectively exit cell cycle and continued to proliferate, resulting in increased cell death.

Finally, it must be noted that the NG2+ cells in Olig1-null mice were morphologically far simpler than in control mice, with fewer processes (Fig. $2 D^{\prime}, E^{\prime}$ ), suggesting a role for Olig1 in early OPC differentiation. In summary, these findings provide evidence that Olig1 is important for pre-OPC to OPC commitment and subsequent OPC differentiation and morphogenesis.

\section{Oligodendrocyte differentiation was reduced, but not the initiation of axon wrapping in P8 Olig1-null mice}

We next investigated the impact of Olig1 loss on the initial stages of myelination in P8 mice. At this age, myelination had already begun in the striatum and lateral corpus callosum of Olig1 control mice (Fig. $3 A$ ), but it was significantly reduced in Olig1-null mice (Fig. 3B). The tissue was stained for Sox10, PDGFR $\alpha$ and $\mathrm{CC} 1$, and as at earlier ages, there were $43 \%$ fewer oligodendrocyte lineage cells (Sox 10+) in Olig1-null mice, with a smaller reduction in the number of PDGFR $\alpha+$ OPCs and a greater reduction in the number of CC1+ mature cells (Fig. 3C, D,E,F). Thus, as a percentage of the total Sox $10+$ oligodendrocyte lineage cells, the progenitor cell population was increased by $27 \%$, while the differentiated cell population was reduced by $32 \%$ (Fig. $3 F$ ), which suggested that, in addition to the delay in cell cycle exit, loss of Olig1 also delayed differentiation of the progenitor cells.

As OPCs differentiate, they move through a premyelinating stage to the myelinating stage (Trapp et al., 1997). It was important to assess whether the reduction of $\mathrm{CC} 1+$ cells resulted from an inability to begin to differentiate, or rather an inability to interact with axons and start myelination. At P8, a higher percentage of the Sox $10+$ cells remained as PDGFR $\alpha+$ progenitor

\footnotetext{
(Figure legend continued.) corpus callosum of P8 Olig1 heterozygous $(J)$ versus Olig1-null mice $(\boldsymbol{K})$, showing that initial axon contact $\left(\boldsymbol{J}^{\prime}, \boldsymbol{K}^{\prime}\right.$, open arrowhead); wrapping $\left(\boldsymbol{J}^{\prime \prime}, \boldsymbol{K}^{\prime \prime}\right.$, arrowhead), and myelin elongation ( $\boldsymbol{J}^{\prime \prime \prime}, \boldsymbol{K}^{\prime \prime \prime}$, arrowhead) were not disrupted. Scale bars: in $\boldsymbol{J}, \boldsymbol{K}, 20$ $\mu \mathrm{m} ; \boldsymbol{J}^{\prime}, J^{\prime \prime}, \boldsymbol{J}^{\prime \prime}, \boldsymbol{K}^{\prime}, \boldsymbol{K}^{\prime \prime}, \boldsymbol{K}^{\prime \prime \prime}, 5 \mu \mathrm{m}$. L, M, High-magnification merged images of myelinating oligodendrocytes marked with PLP (green), MBP (red), and neurofilament (blue) showing that the myelin processes appeared relatively normal and were not reduced in Olig1-null $(\boldsymbol{M})$ versus control (L) mice. Scale bar, $30 \mu \mathrm{m}$. For all quantifications, mean \pm SEM; ${ }^{*} p<0.05{ }^{* * *} p<$ $0.0005,{ }^{* * * *} p<0.0005,{ }^{* * * * *} p<0.0000005$; unpaired Student's $t$ test).
}

cells, and fewer were premyelinating PLP+ cells (Fig. 3G,H). Thus, PLP + premyelinating oligodendrocytes only accounted for $7.2 \%$ of total Sox $10+$ cells in Olig1-null mice, far less than the $20.6 \%$ seen in control tissue (Fig. 3I). Thus, the initiation of differentiation from OPC to premyelinating oligodendrocyte was impaired in these mice.

As noted above, by $\mathrm{P} 8$, myelination was occurring rapidly in the subcortical white matter of control animals, but this was rarely seen in Olig1-null mice, where only limited myelination was seen in the lateral corpus callosum (Fig. $3 A, B$ ). This likely resulted only from the reduced numbers of $\mathrm{CC} 1+/ \mathrm{Sox} 10+$ mature oligodendrocytes, because those that did differentiate had no deficit in initial axonal contact. Thus, the initial axonal contact, which appeared to involve PLP-expressing membranes (Fig. $3 J^{\prime}, K^{\prime}$, arrowhead), and further wrapping and segment elongation, which involved membranes containing both PLP and MBP (Fig. $3 J^{\prime \prime}, J^{\prime \prime \prime}, K^{\prime \prime}, K^{\prime \prime \prime}$, arrowheads), were relatively normal in Olig1null (Fig. 3K), compared with control littermates (Fig. 3J). Indeed, as these cells continued to myelinate, they appeared relatively comparable to control cells (Fig. $3 L, M$ ). These data indicate that, in addition to a role of Olig1 in early OPC cell cycle exit, the loss of Olig1 impacted terminal differentiation of oligodendrocytes, but for cells that had terminally differentiated, Olig1 was not essential for myelination initiation per se.

\section{Oligodendrocyte deficit persists in the brain of adult Olig1- null mice}

An important question was whether the reduced oligodendrocyte number and impaired differentiation in Olig1-null corpus callosum eventually recovered as the animals matured. Oligodendrocyte maturation and myelination were therefore investigated in 2 month Olig1-null corpus callosum. Consistent with the early developmental stages, the number of Sox $10+$ cells at the midline of the corpus callosum of Olig1-null mice was reduced by $\sim 60 \%$ relative to control. This reduction resulted primarily from a reduction in mature oligodendrocytes, since there was a $68 \%$ reduction of the total number of $\mathrm{CC} 1+$ mature oligodendrocytes in Olig1-null mice, whereas the PDGFR $\alpha+$ OPC numbers were not different from those of control littermates (Fig. 4A-C). Within the oligodendrocyte population in Olig1-null mice, the percentage of mature oligodendrocytes was reduced $\sim 18 \%$ in Olig1-null mice compared with control, whereas the population that remained OPCs doubled (Fig. 4D). This sharp reduction of mature oligodendrocytes had a profound impact on myelination in Olig1-null mice. Immunofluorescent quantification of the major myelin proteins PLP and MBP indicated that both PLP and MBP were decreased by $60 \%$ in Olig1-null mice, compared with control (Fig. 4E, G,I), and there appeared to be far more unmyelinated axons in Olig1-null mice, in contrast to the intensively stained myelin in control samples (Fig. 4F, $H$ ).

To establish whether there were in fact more unmyelinated axons and to further assess the impact of Olig1 loss, samples were analyzed by electron microscopy, and consistent with the immunofluorescence data, the number of unmyelinated axons in the Olig1-null animal was increased approximately twofold (Fig. $5 A, B, F)$, and the number of myelinated axons was reduced by $47 \%$ in midline corpus callosum of Olig1-null mice relative to control mice (Fig. $5 A, B, E$ ). Furthermore, this deficit remained in 6- and 15-month-old Olig1-null mice (data not shown), excluding the possibility that over time there was long-term recovery. However, as with the data indicating that the few cells that terminally differentiated in Olig1-null mice had no problem beginning myelination (Fig. $3 \mathrm{~J}, \mathrm{~K}$ ), the $g$-ratios for those axons that were 

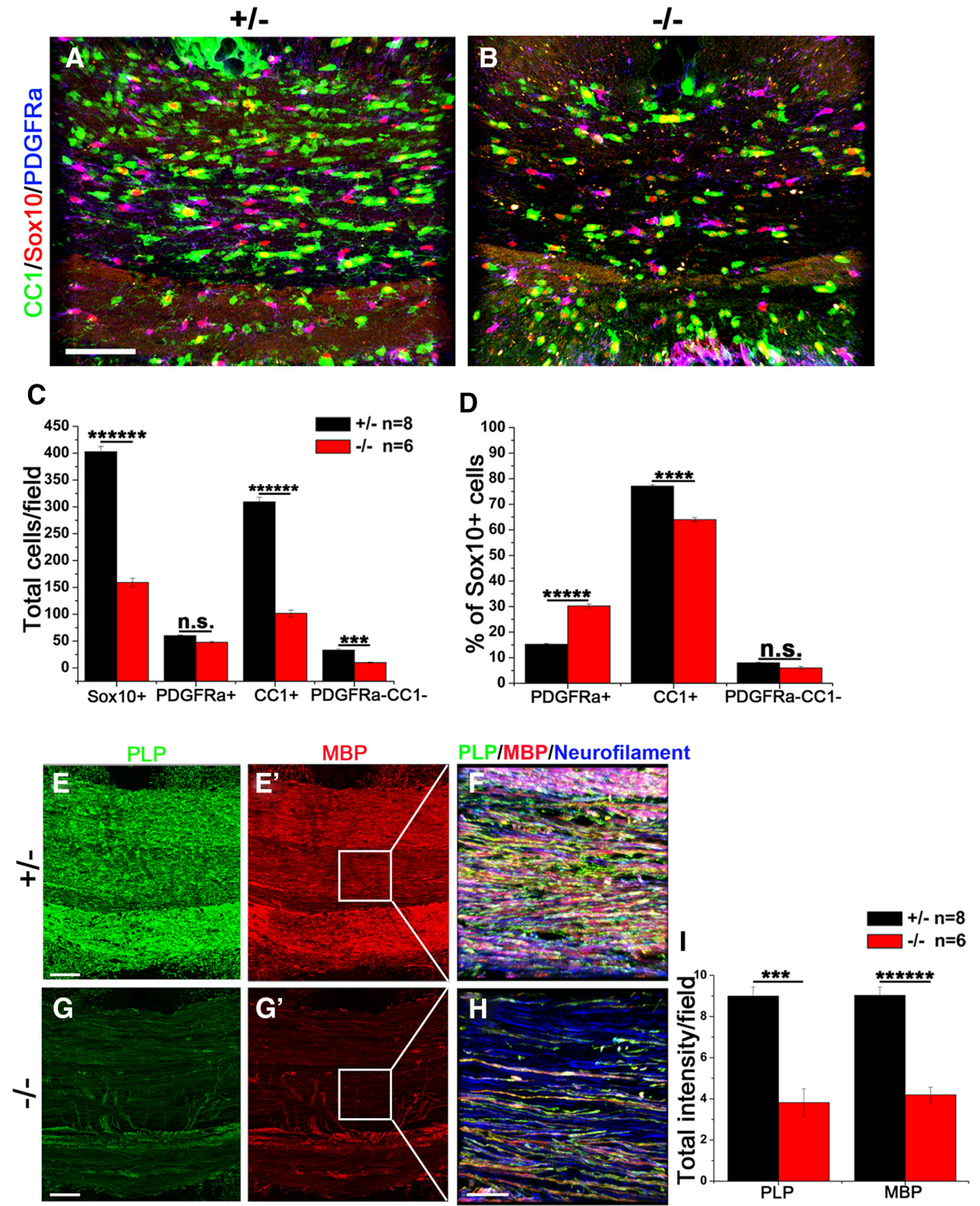

Figure 4. Oligodendrocyte maturation and myelination in adult brain of Olig1-null mice. $A, B$, Representative images showed staining of oligodendrocyte lineage cells (Sox10+; red), OPCs (PDGFR $\alpha+$; blue) and mature oligodendrocytes (CC1+; green) in midline corpus callosum of 2 month Olig1-null ( $\boldsymbol{B})$ versus heterozygous mice $(\boldsymbol{A})$. Scale bar, $50 \mu \mathrm{m}$. $\boldsymbol{C}, \boldsymbol{D}, \mathbf{Q}$ Quantification of total number $(\boldsymbol{C})$ or percentage $(\boldsymbol{D})$ of mature oligodendrocytes (CC $1+)$, OPCs (PDGFR $\alpha+$ ), and immature oligodendrocytes (PDGFRa $-/ C(1-)$ as shown in $A$ and $\boldsymbol{B}$, demonstrated a persisted blockage of oligodendrocyte maturation in Olig1-null mice. $\boldsymbol{E}, \boldsymbol{G}$, Representative images showed reduced myelin protein: PLP (green) and MBP (red) staining in midline of corpus callosum of 2-month-old Olig1-null (G) versus heterozygous mice $(\boldsymbol{E})$. Scale bar, $50 \mu \mathrm{m}$. $\boldsymbol{F}, \boldsymbol{H}$, High-magnification merged images corresponding to box insets in $\boldsymbol{E}$ and $\boldsymbol{G}$ with PLP (green), MBP (red), and neurofilament (blue) showing many unmyelinated axons in Olig1-null $(\boldsymbol{H})$ versus Olig1 heterozygous $(\boldsymbol{F})$ mice. Scale bar, $20 \mu \mathrm{m}$. $\boldsymbol{I}$, Quantification of $\left(\mathrm{TCF}\right.$ of PLP and MBP staining in Olig1 heterozygous $\left(\boldsymbol{E}, \boldsymbol{E}^{\prime}\right)$ versus Olig1-null $\left(\boldsymbol{G}, \mathbf{G}^{\prime}\right)$ mice. For all quantifications, mean \pm SEM; $n=8$, Olig1-het; $n=6$, Olig1-null; ${ }^{* *} p<0.0005,{ }^{* * *} p<0.00005,{ }^{* * * * *} p<0.0000005$; unpaired Student's $t$ test).

myelinated were essentially normal (Fig. 6C,D). Despite the persistent hypomyelination in the Olig1-null mouse, no axonal degeneration at the ultrastructural level was observed (Fig. 6B) and the total number of axons was not statistically different compared with control (Fig. 6G). In addition, axonal degeneration was further evaluated by SMI32 antibody staining of the nonphospho- rylated form of neurofilament, and no significant accumulation of SMI32 was observed in Olig1-null mice at 2 months of age (data not shown).

Western blot studies confirmed the overall reduction in myelin in Olig1-null brain. Consistent with the immunofluorescent studies, total myelin protein was reduced in the Olig1-null cere- 

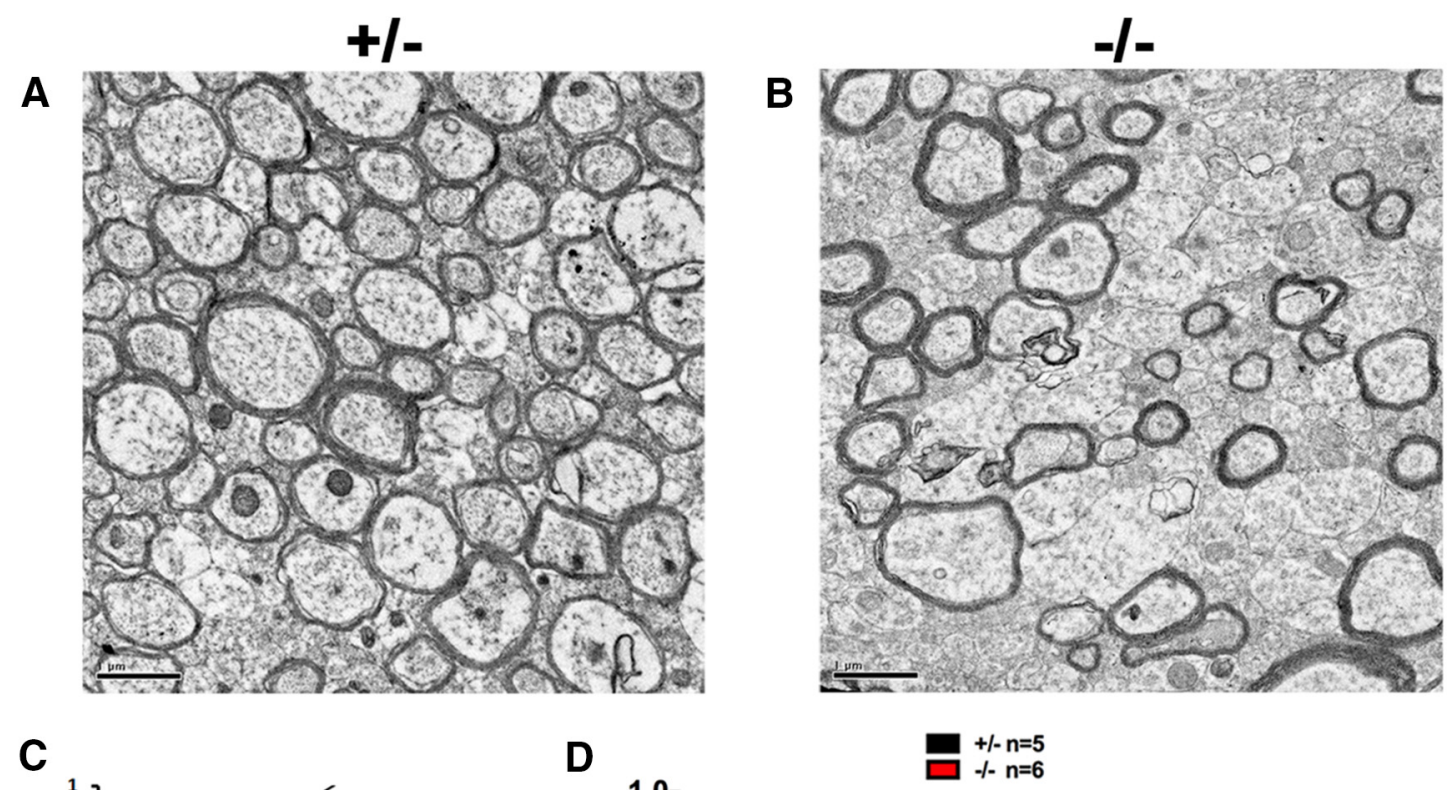

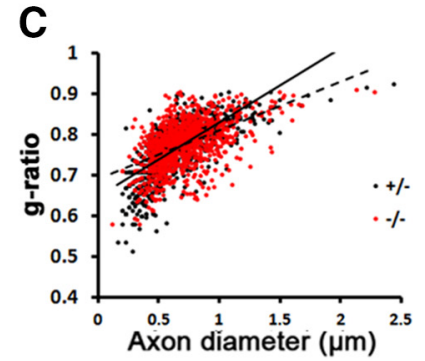

E

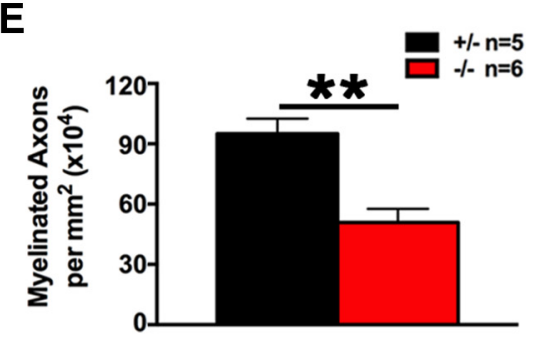

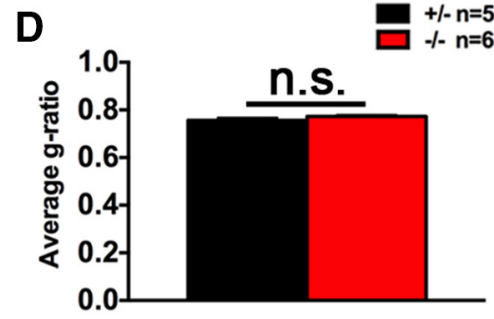

$F$

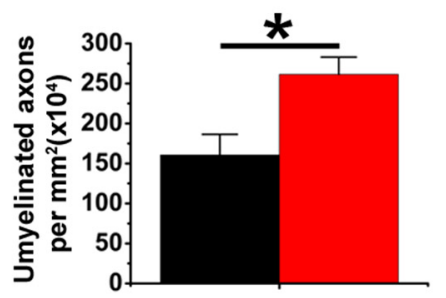

G

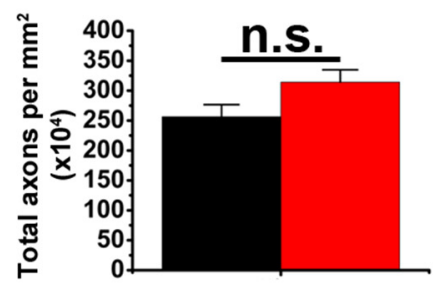

Figure 5. The corpus callosum is hypomyelinated in Olig1-null mice. $A, B$, Electron micrographs of midline corpus callosum in sagittal sections of Olig 1 heterozygous $(\boldsymbol{A})$ versus null ( $\boldsymbol{B})$ mice at 2 months. The reduction in the number of myelin sheaths is evident. Scale bar, $1 \mu \mathrm{m} . C, D, Q$ uantification of the $g$-ratio as a scatter plot with axonal diameter on the $x$-axis and $g$-ratio on the $y$-axis, $(+/-)$ solid line; (-I-) dashed line ( $(\boldsymbol{C}$, or average value (D); no overall difference of $g$-ratio was noted. $\boldsymbol{E}-\boldsymbol{G}$, Myelinated, unmyelinated and total axons were counted in at least 10 randomly selected, nonoverlapping fields from midline sagittal sections of the corpus callosum. The number of myelinated axons $(\boldsymbol{E})$, unmyelinated axons $(\boldsymbol{F})$, and total number of axons $(\boldsymbol{G})$ per square millimeter of Olig 1 heterozygous versus Olig1-null was calculated corresponding to $A$ and $\boldsymbol{B}$. For all quantifications, mean \pm SEM; $n=8$, Olig1-het; $n=6$, Olig1-null; ${ }^{* *} p<0.005$; unpaired Student's $t$ test).

brum. Myelin proteins were quantified by Western blot, and at $\mathrm{P} 15$, there was already reduced myelin in Olig1-null cerebrum (Fig. 6A,C), which persisted in 2-month-old Olig1-null mice (Fig. 6B,D).

Developmental recovery and normal myelination in the spinal cord of adult Olig1-null mice

The original report of these Olig1-null mice indicated that loss of Olig1 did not result in significant dysmyelination in embryonic spinal cord (Lu et al., 2002). To confirm that these mice retained that phenotype, we analyzed oligodendrocyte development and myelination in spinal cord. By P8, the majority of the axons both in the gray and white matter of cervical spinal cord in control mice were myelinated (Fig. 7A). However, myelination was delayed in the gray matter of Olig1-null spinal cord, and numerous axons were not yet myelinated in both the dorsal and ventral columns (Fig. 7B). Strikingly, however, PLP and MBP immunofluorescence in Olig1-null spinal cord appeared relatively normal by 2 months (Fig. $7 C, E$ ), suggesting recovery from the early def- icit in the spinal cord. At this time point, the majority of axons in the dorsal column were myelinated both in Olig1-null and control mice (Fig. $7 D, F$ ). Electron micrographs indicated that myelination appeared normal in the 2-month-old Olig1-null spinal cord (data not shown), which is consistent with the Arnett et al. (2004) study of Olig1-null spinal cord. Interestingly, despite the apparently normal myelin in Olig1-null spinal cord, there was still a $35 \%$ reduction of total Sox $10+$ oligodendrocytes. This was attributable primarily to a nearly $40 \%$ loss of CC1+ mature oligodendrocytes in Olig1-null spinal cord, compared with control littermates (Fig. $7 G-I$ ). Thus, in contrast to brain, where less mature oligodendrocytes resulted in reduced myelination, in spinal cord, there was some loss of oligodendrocytes, but the percentage of OPCs and mature oligodendrocytes was only modestly different between Olig1-null and control mice (Fig. $7 J$ ) and myelin appeared normal.

The relatively minor impact on myelination from the loss of Olig1 in spinal cord was quantified by Western blot analysis of total spinal cord. The myelin deficit had almost recovered by P15 
A

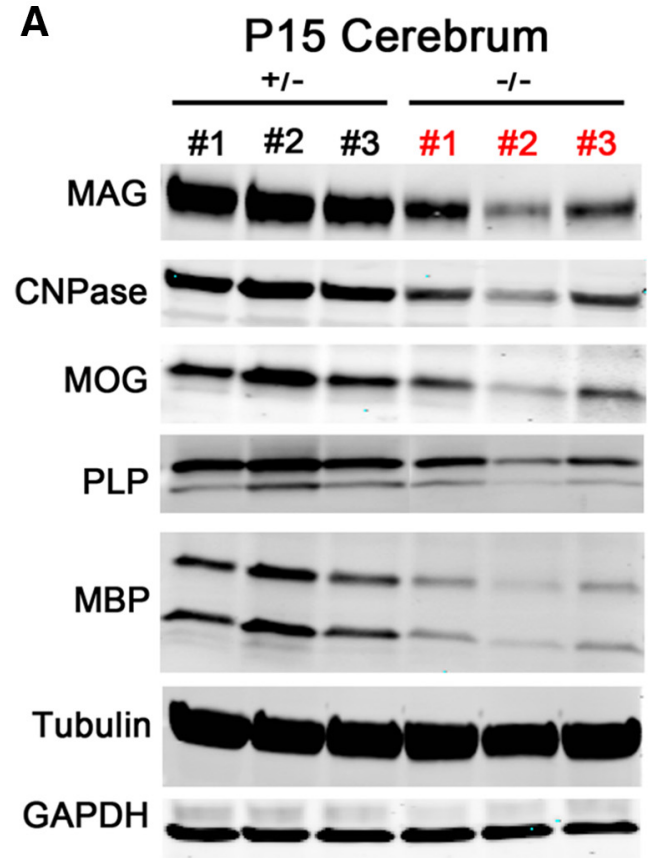

C

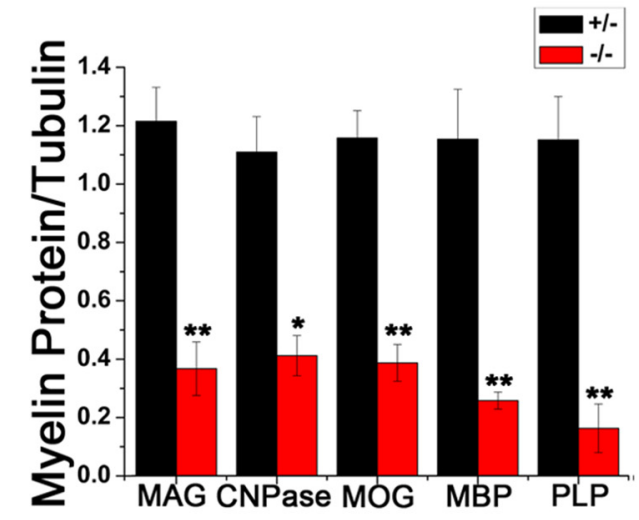

B 2 month Cerebrum

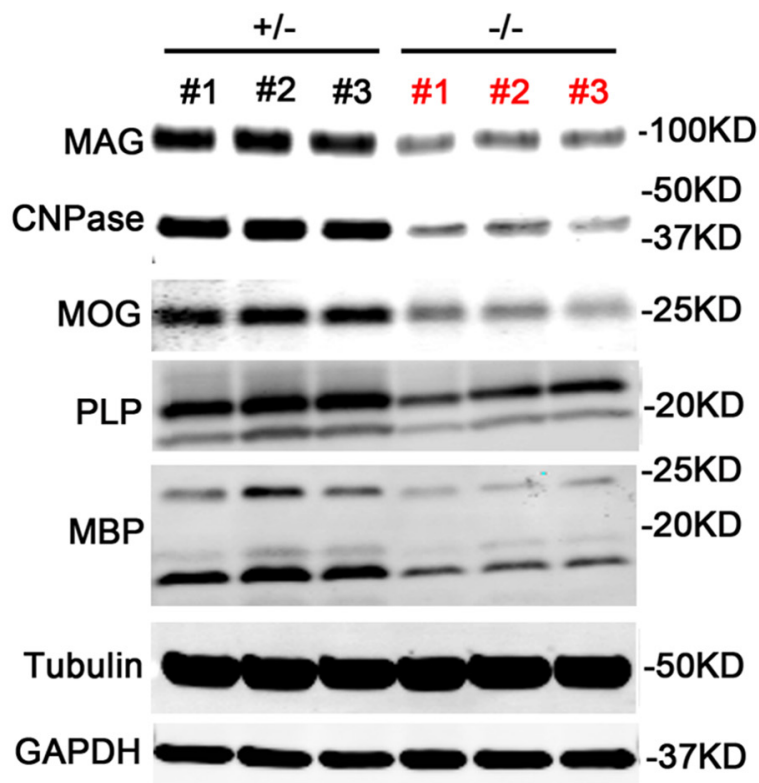

D

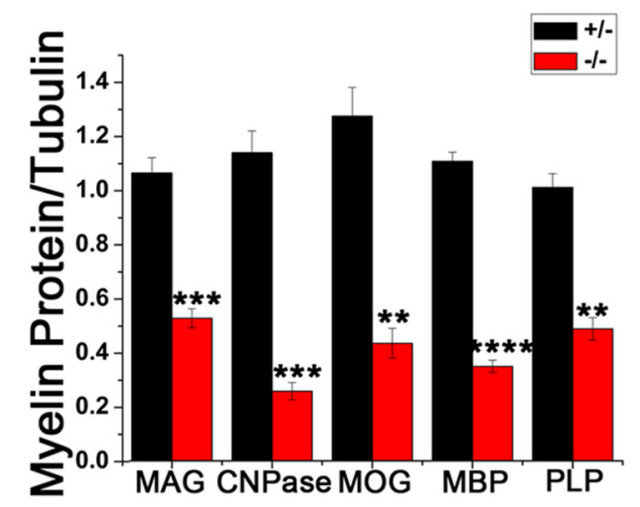

Figure 6. Major myelin protein expression in cerebrum of P15 and 2-month-old Olig1-null mice. $A, B$, Representative Western blot of major myelin proteins (MAG, CNPase, MBP, PLP, and MOG) from P15 ( $\boldsymbol{A}$ ) and 2-month-old ( $\boldsymbol{B}$ ) cerebrum lysates of Olig 1 heterozygous (black) versus Olig 1 null (red) mice. Three samples from each genotype are shown. $\boldsymbol{C}, \boldsymbol{D}$, Quantification of the intensity of Western blot bands of $\mathrm{P} 15(\boldsymbol{C})$ and 2-month-old ( $\boldsymbol{D}$ ) cerebrum lysates of Olig 1 heterozygous (black column) versus Olig 1 -null (red column) mice shown in $\boldsymbol{A}$ and $\boldsymbol{B}$. Individual myelin protein intensity of Olig 1 heterozygous samples was set to 1 based on averaging the actually numeric values, and Olig1-null values were graphed as percentage of control. For all quantifications, mean \pm SEM; $n=$ 6, Olig1-het versus $n=6$, Olig1-null; ${ }^{*} p<0.05,{ }^{* *} p<0.005,{ }^{* * *} p<0.0005,{ }^{* * * *} p<0.00005$; paired Student's $t$ test).

(Fig. $8 A, C$ ), and had recovered even more so by 2 months (Fig. $8 B, D)$. These data dramatically contrasted with the major difference in myelin proteins in cerebrum (Fig. 6).

Collectively, these data indicate that although the number of mature oligodendrocytes was sharply reduced in both brain and spinal cord of Olig1-null mice, OPC differentiation in spinal cord was relatively normal, and the remaining mature oligodendrocytes generated essentially normal amounts of myelin in the spinal cord. These data are consistent with the initial report of these mice (Lu et al., 2002).

Expression and subcellular location of Olig1 is highly coordinated with oligodendrocyte morphogenesis and the onset of myelination

Olig1 and Olig2 are highly conserved at the molecular and functional level, yet they have distinct subcellular localization in mature oligodendrocytes (Arnett et al., 2004). Olig1 is initially found in the nucleus of OPCs and as oligodendrocytes mature, Olig1 translocates to the cytoplasm of myelinating oligodendrocytes.
The role for Olig1 in the cytoplasm is unclear, but our studies suggest that it may be a regulated event. We analyzed Olig1 expression in wild-type mice during the transition from premyelinating to myelinating oligodendrocytes. Strikingly, Olig1 was undetectable in premyelinating oligodendrocytes right before they contacted axons and in oligodendrocytes that were initiating axon contact (Fig. 9A,B,D,E, arrowheads). Olig1 expression then gradually increased in the cytoplasm of myelinating oligodendrocyte as myelinogenesis proceeded (Fig. 9C,F, arrowheads). This dynamic Olig1 expression and localization was even more apparent in single cells costained for both Sox10 and Olig2 (Fig. 9G-J). Furthermore, colabeling with PDGFR $\alpha$ (OPC) and PLP (premyelinating oligodendrocytes) confirmed stage-specific reduction of Olig1 in the premyelinating oligodendrocyte population (Fig. $9 K, L)$.

Olig2 expression was not altered in Olig1-null brain

In earlier reports, it had been suggested that the mild impact of Olig1 loss might result from compensatory increases in Olig2 

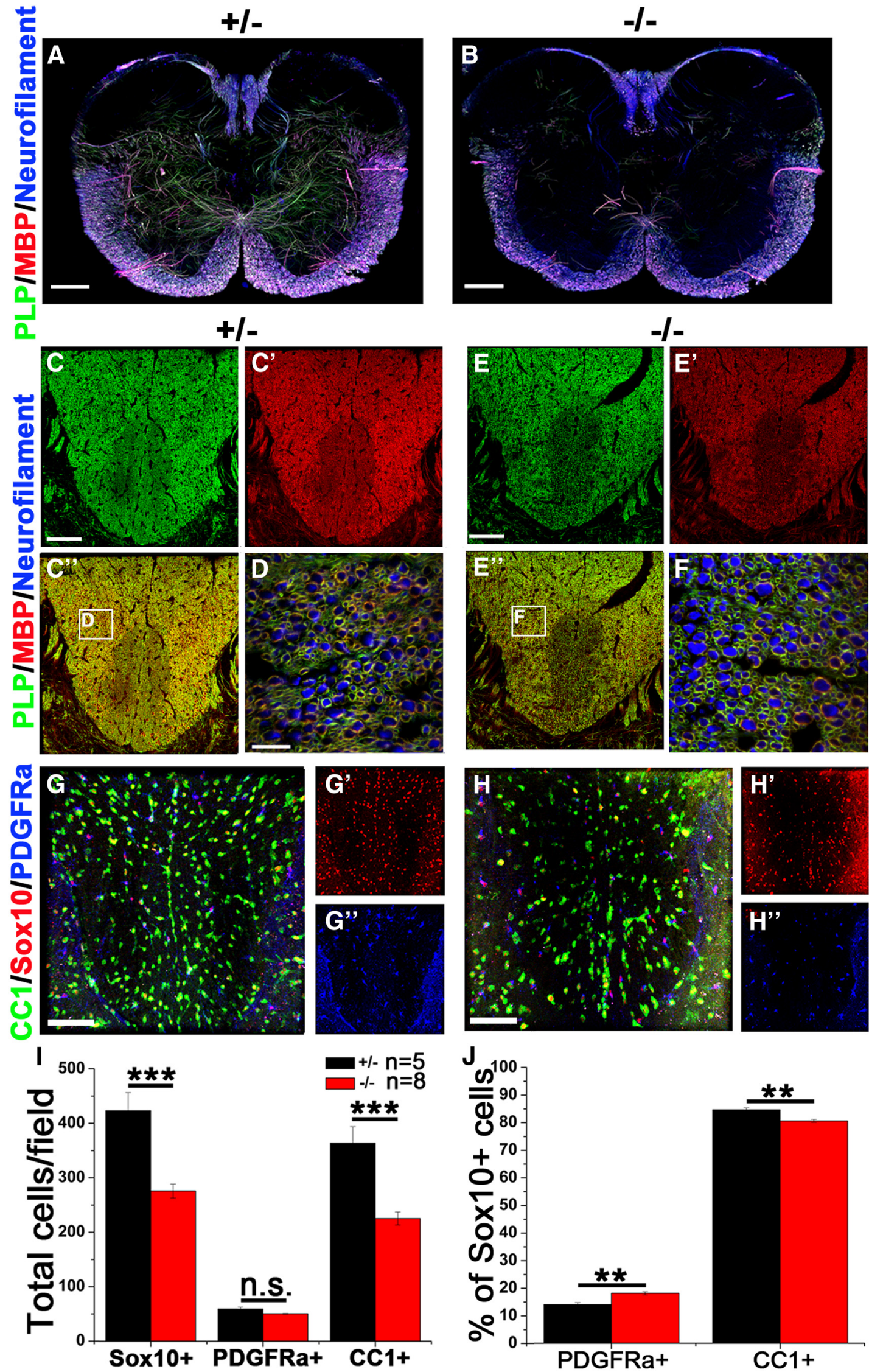

Figure 7. Adult Olig1-null spinal cord had fewer oligodendrocytes, but apparently normal myelination. $A, B$, Low-magnification images of P8 whole cervical spinal cord stained with PLP (green), MBP (red) and neurofilament (blue) showing delayed myelination in Olig1-null ( $\boldsymbol{B}$ ) versus Olig1 heterozygous ( $\boldsymbol{A}$ ) mice. Scale bar, $200 \mu \mathrm{m}$. C, $\boldsymbol{E}$, Representative images of PLP (green) and MBP (red) staining of dorsal column of cervical spinal cord from 2-month-old Olig1 heterozygous $\left(\boldsymbol{C}, \boldsymbol{C}^{\prime}, \boldsymbol{C}^{\prime \prime}\right)$ versus Olig1-null $\left(\boldsymbol{E}, \boldsymbol{E}^{\prime}, \boldsymbol{E}^{\prime \prime}\right)$ mice. Scale bar, $50 \mu \mathrm{m}$. $\boldsymbol{D}, \boldsymbol{F},($ Figure legend continues.) 

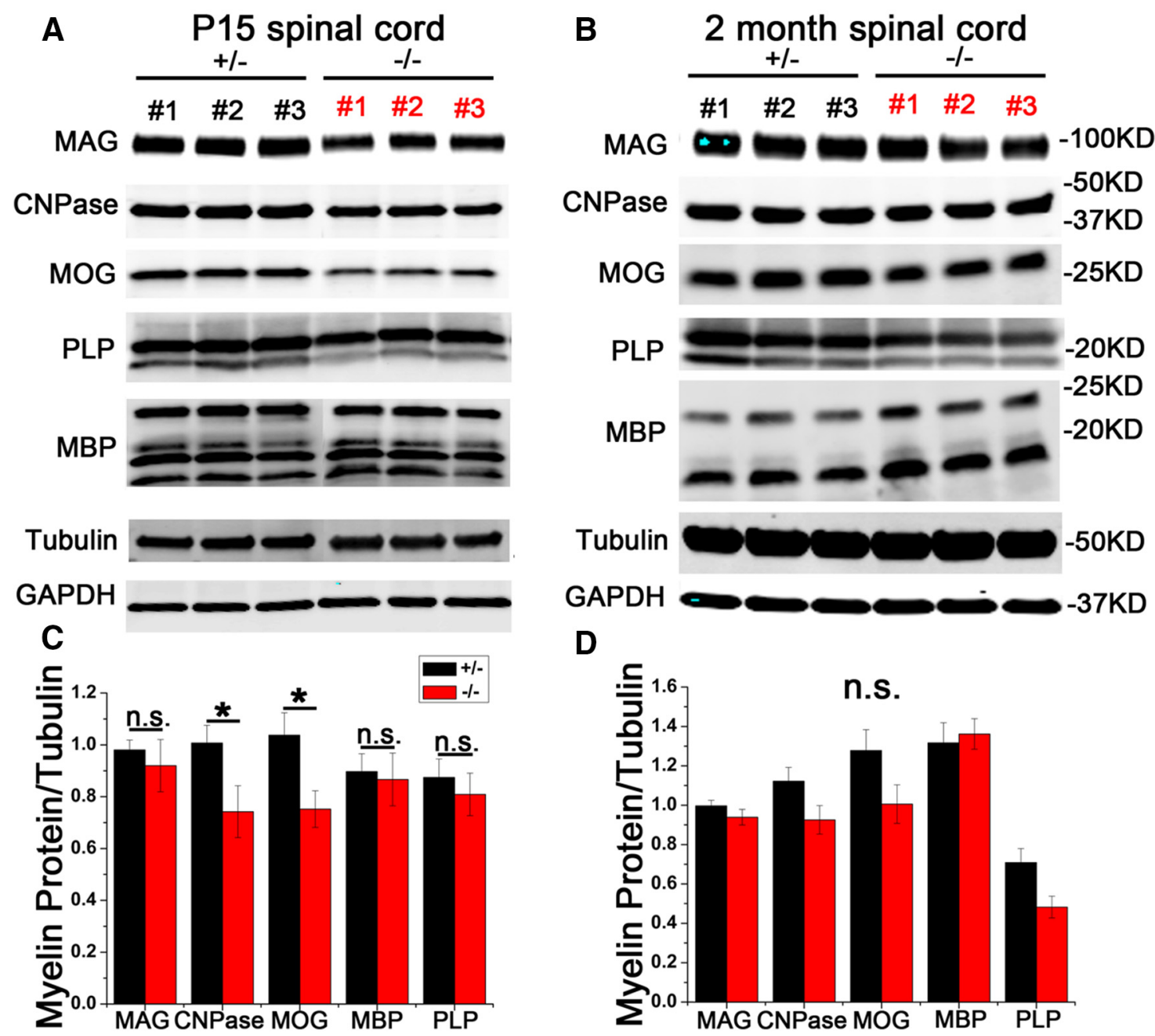

Figure 8. Major myelin proteins expression in spinal cord of P15 and 2-month-old Olig1-null mice. $A, B$, Representative Western blot of major myelin proteins (MAG, CNPase, MBP, PLP and MOG) from P15 ( $\boldsymbol{A}$ ) and 2 month $(\boldsymbol{B})$ spinal cord lysates of Olig 1 heterozygous (black) versus Olig 1 null (red) mice, three blots from each genotype were shown. $\boldsymbol{C}, \boldsymbol{D}$, Quantification of the intensity of Western blot bands of P15 ( $C$ and 2 month (D) spinal cord lysates of Olig 1 heterozygous (black column) versus Olig 1 null (red column) mice shown in $\boldsymbol{A}$ and $\boldsymbol{B}$. For all quantifications, individual myelin protein intensity of Olig 1 heterozygous was set to 1 based on averaging the actually numeric values, and that of Olig 1 -null values were graphed as percentage of control. For all quantifications, mean \pm SEM; $n=6( \pm)$ versus $n=6(-1-) ;{ }^{*} p<0.05$; paired Student's $t$ test $)$.

expression (Lu et al., 2002). We therefore analyzed Olig2 expression in P1, P8, P15, and 1-month-old Olig1-null and control mice (Fig. 10A-D). No obvious dysregulation of Olig2 was seen in Olig1-null oligodendrocytes in subcortical white matter by immunohistochemical analysis (Fig. $10 A-D$ ). To confirm this, Olig2 in cerebrum and spinal cord was quantified by Western blot at P15 and 2 months. Olig2 protein expression was reduced by $60 \%$ in the cerebrum of both P15 and 2-month-old Olig1-null mice compared with control littermates (Fig. 10E), which was consistent with the

$\leftarrow$

(Figure legend continued.) High-magnification merged images corresponding to labeled box inset in $\left(\boldsymbol{C}^{\prime \prime}\right)$ and $\left(\boldsymbol{E}^{\prime \prime}\right)$ showing that most axons were myelinated in both Olig1 heterozygous $(\boldsymbol{D})$ and Olig1 null (F) spinal cord. Scale bar, $10 \mu \mathrm{m}$. $\mathbf{G}, \boldsymbol{H}$, Representative images showing staining of mature oligodendrocytes (CC1; green), oligodendrocyte lineage cells (Sox10; red) and OPCs (PDGFR $\alpha$; blue) in cervical spinal cord of 2-month-old Olig1-null $(\boldsymbol{H})$ versus heterozygous $(\boldsymbol{G})$ mice. Scale bar, $50 \mu \mathrm{m}$. Small inset (right) adjacent showing the total Sox10+ oligodendrocytes $\left(\boldsymbol{G}^{\prime}, \boldsymbol{H}^{\prime}\right)$ and PDGFR $\alpha+\mathrm{OPCS}\left(\boldsymbol{G}^{\prime \prime}, \boldsymbol{H}^{\prime \prime}\right)$ correspondingly. $\boldsymbol{I}, \boldsymbol{J}$, Quantification of total number $(\boldsymbol{I})$ or percentage $(\boldsymbol{J})$ of OPCS (PDGFR $\alpha+)$, mature oligodendrocytes $(\mathrm{CC} 1+)$ as shown in $\boldsymbol{G}$ and $\boldsymbol{H}$ in lateral corpus callosum of Olig 1 heterozygous versus 0 lig 1 null mice. For all quantifications, mean \pm SEM; $n=5$, Olig1-het versus $n=8$, Olig1-null; ${ }^{* *} p<0.005,{ }^{* * *} p<0.0005$; unpaired Student's $t$ test. $\sim 60 \%$ reduction in total oligodendrocytes. Thus, on a per cell basis, these data suggest little change in Olig2 expression, and in particular no compensatory increase of Olig2 in cerebrum. In contrast, although we observed a $40 \%$ reduction of Olig2 in spinal cord of P15 Olig1-null mice by Western blot (Fig. 10F), Olig2 expression in Olig1-null spinal cord was comparable to control spinal cord by 2 months (Fig. 10F). Because the total oligodendrocyte number was decreased $\sim 35 \%$ in Olig1-null spinal cord, this finding suggests that by 2 months, the Olig2 level may actually be upregulated in individual oligodendrocytes in the Olig1-null spinal cord. An approximation of the amount of Olig2/cell was calculated for 2-month-old tissue, using data from the cell number and Western blot studies (Fig. 10F). Collectively, these results suggest that there was no compensatory change in Olig2 expression in cerebrum, where there was severe dysmyelination, but intriguingly there was potentially compensatory upregulation of Olig2 in spinal cord, where less dysmyelination was seen.

Olig1 is important for initial oligodendrocyte differentiation in vitro

To expand on the in vivo studies of Olig1-null OPCs, we examined the impact of Olig1 loss on proliferation and differentiation 

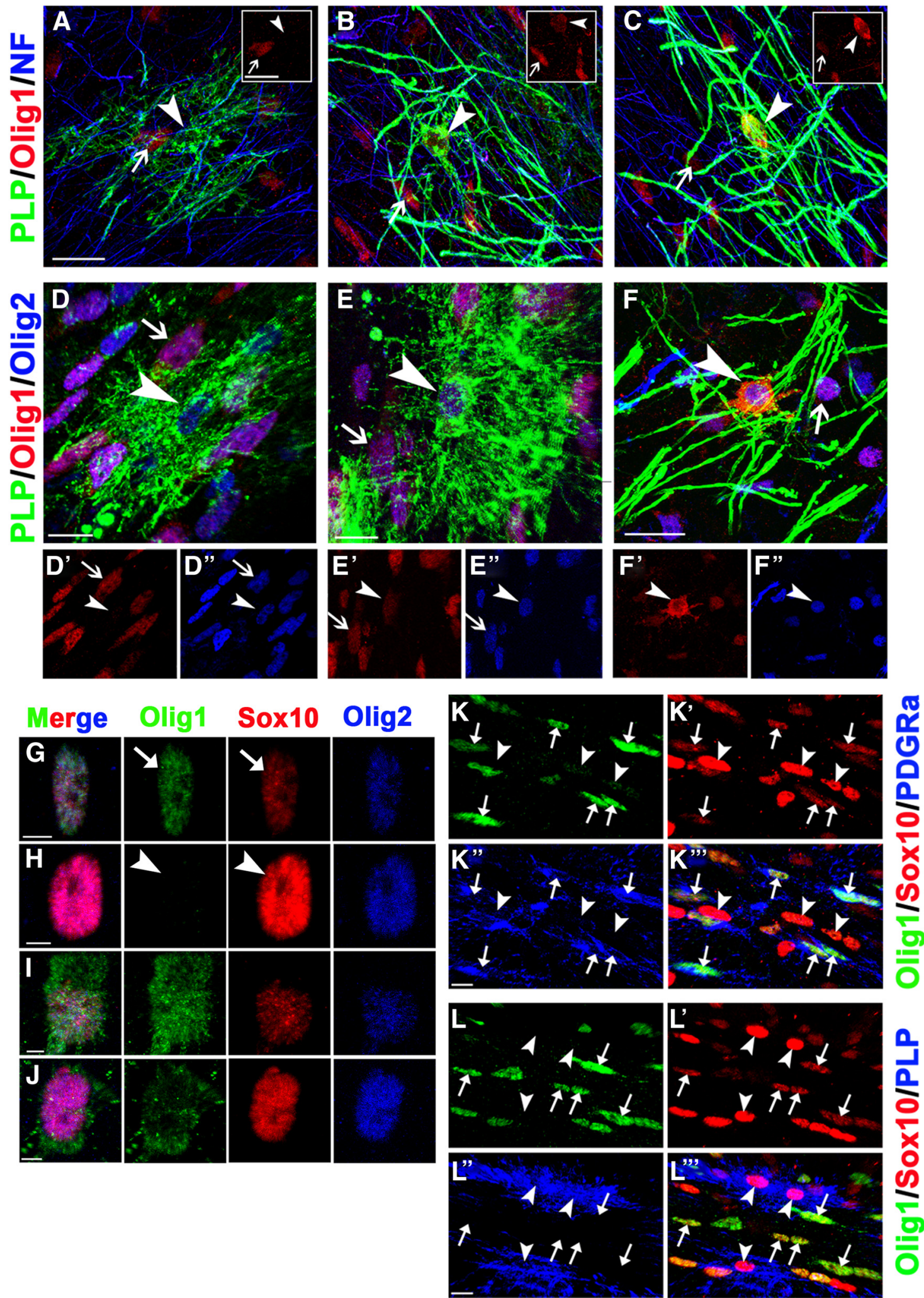

Figure 9. Expression and subcellular location dynamics of Olig1 upon myelination onset. Representative images of premyelinating and myelinating oligodendrocytes were labeled with PLP (green), Olig1 (red) either costained for neurofilament ( $\boldsymbol{A}-\boldsymbol{C}$; blue) or 0lig2 $(\boldsymbol{D}-\boldsymbol{E}$; blue) in cortex of P8 wild-type mice. Box insets show 0lig1 protein absent from premyelinating 0Ls (A, $\boldsymbol{D}$, arrowhead) and reappeared in cytoplasm of active myelinating oligodendrocytes ( $\boldsymbol{C}, \boldsymbol{F}$, arrowhead), whereas it is localized in the nucleus in surrounding OPCs (bar-arrow). Scale bar, $\boldsymbol{A}-\boldsymbol{E}, 20 \mu \mathrm{m}$; $F, 10 \mu \mathrm{m} . \mathbf{G}-J$, Representative images of a single nucleus showed dynamic 0lig1 expression and localization in maturing oligodendrocytes within the corpus callosum of P8 wild-type mice. Scale bar, $1.5 \mu \mathrm{m} . \boldsymbol{K}, \boldsymbol{L}$, Representative images of Olig1 (green) localization in OPCS (PDGFR $\alpha+$; blue; $\boldsymbol{K}$ ) and premyelinating oligodendrocytes (PLP+; blue; $\boldsymbol{L}$ ) corresponding to cells labeled in $\boldsymbol{G}, \boldsymbol{H}$. Arrow, OPCs; arrowhead, premyelinating oligodendrocytes. Scale bar, $10 \mu \mathrm{m}$. 

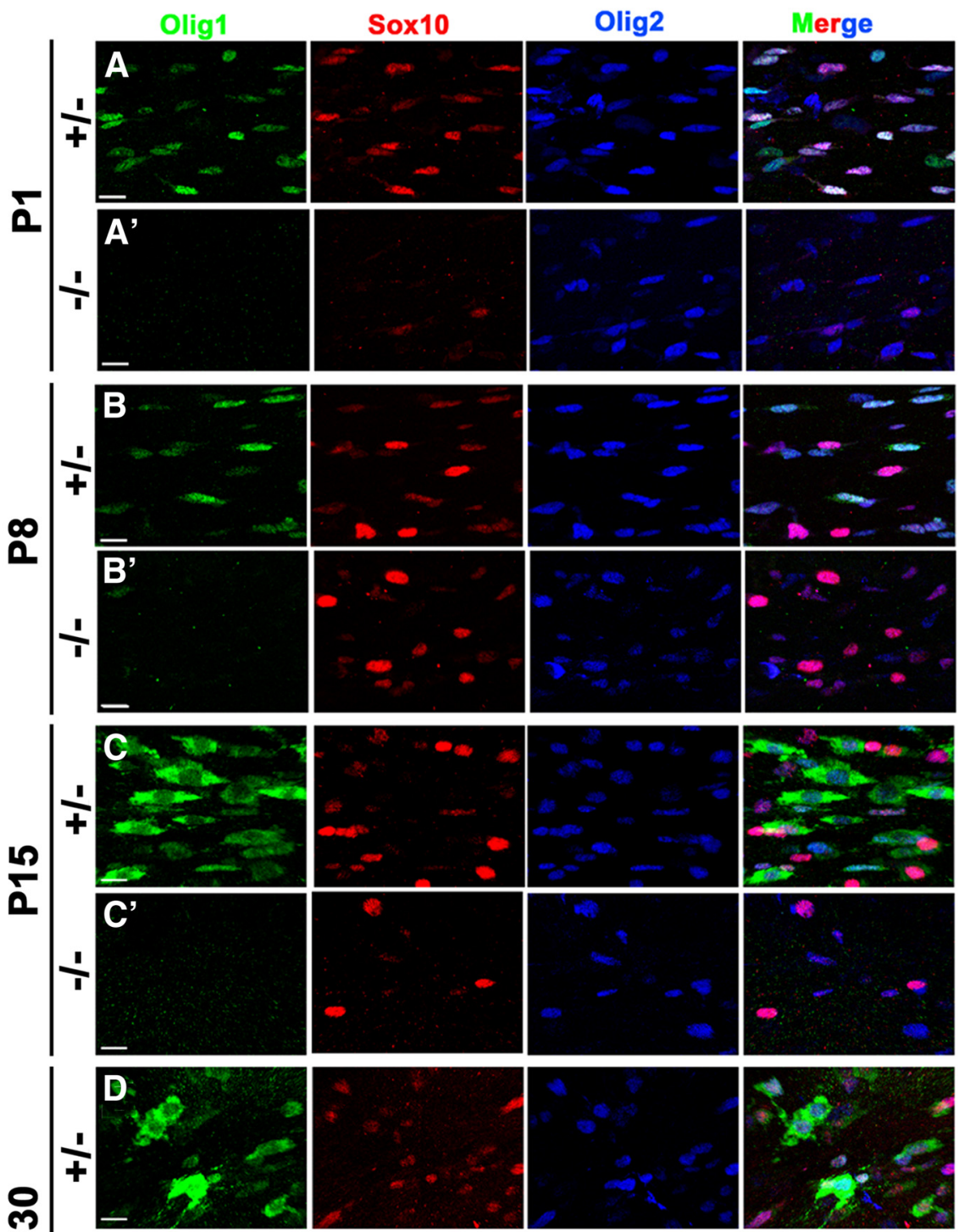

ฉ.
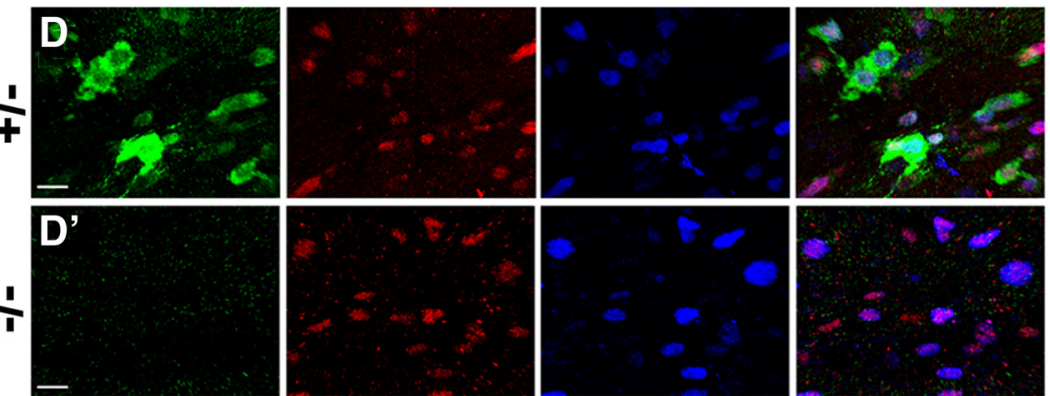

\section{E $\frac{\text { P15 Cerebrum }}{\# 1+2 \pi_{-1}}$}

\section{Olig2 -E $E$}

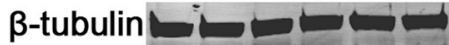

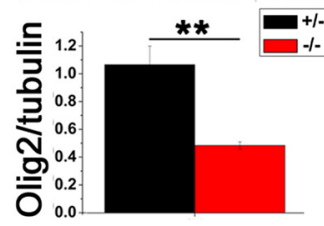

\section{$\frac{2 \text { month Cerebrum }}{\# l_{-}} \frac{-_{--}}{\# 3}$}

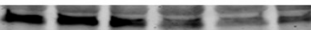
ーㄴ
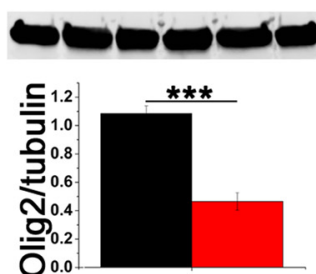
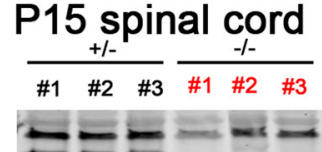
$-1$
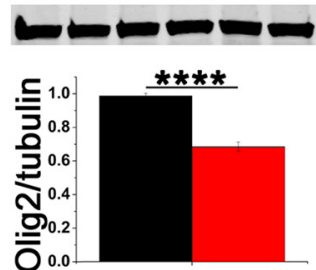

\section{2 month spinal cord}
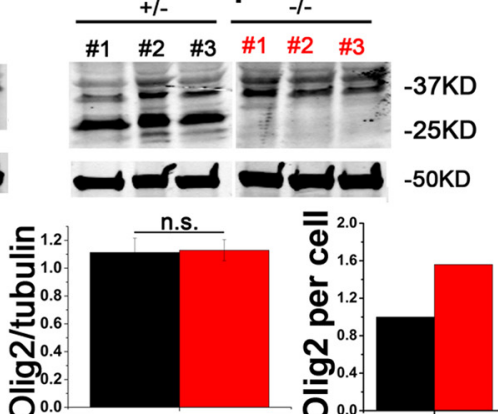

Figure 10. Olig2 expression in the CNS of developing Olig1-null mice. $\boldsymbol{A}-\boldsymbol{D}$, Olig2 expression in developing corpus callosum of Olig1 heterozygous $(\boldsymbol{A}-\boldsymbol{D})$ versus 0 lig 1 null $\left(\boldsymbol{A}^{\prime}, \boldsymbol{B}^{\prime}, \boldsymbol{C}^{\prime}, \boldsymbol{D}^{\prime}\right)$ mice at $\mathrm{P} 1(\boldsymbol{A}), \mathrm{P8}$ $(\boldsymbol{B})$, P15 (C), and 1-month-old (D). The absence of Olig1 expression is confirmed in Olig1-null mice at various stages. Scale bar, $50 \mu \mathrm{m} . \boldsymbol{E}$, $\boldsymbol{F}$, Representative Western blot and quantification of 0lig1 and Olig2 proteins from cerebrum $(\boldsymbol{E})$ and spinal cord $(\boldsymbol{F})$ whole tissue lysates of P15 and 2-month-old Olig 1 heterozygous (black) versus Olig 1 null (red) mice, three blots from each genotype were shown. Olig2 protein intensity was set to 1 for control samples, based on averaging the actual numeric values, and Olig2 protein in Olig1-null mice was graphed as a percentage of control. An estimation of Olig2 level per cell was also quantified in 2-month-old spinal cord by dividing 0lig2 protein values by the number of total oligodendrocytes in control and Olig1-null samples. For all quantifications, mean \pm SEM; $n=6$, Olig1-het versus $n=6$, Olig1-null; ${ }^{* *} p<0.005,{ }^{* * *} p<0.0005,{ }^{* * * *} p<0.00005$; paired Student's t test). 

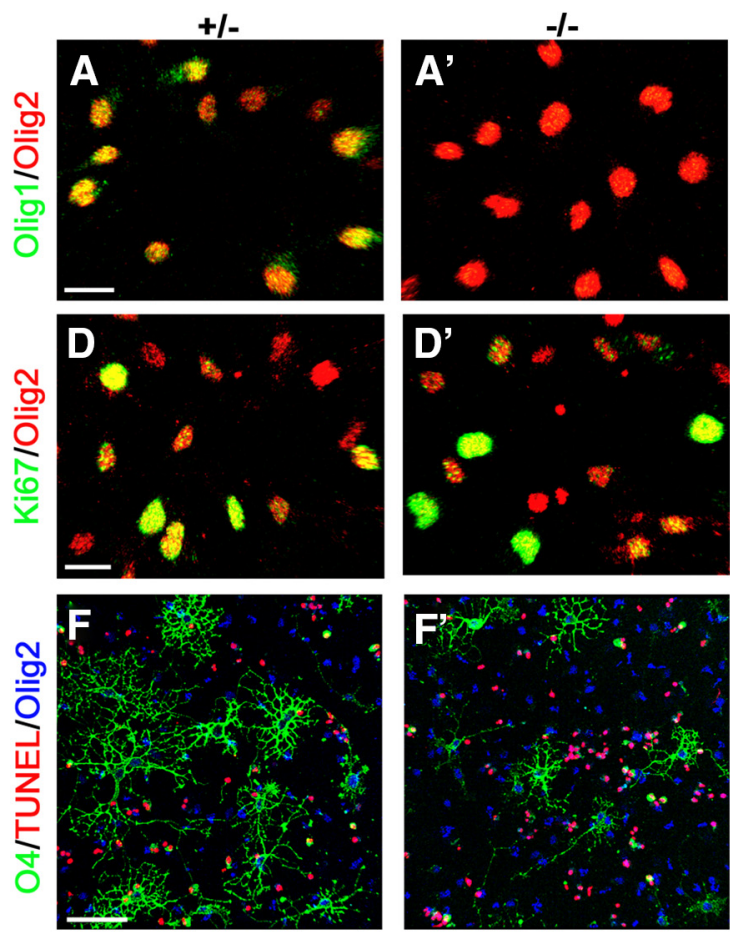

$\mathbf{J}$

\section{PDGF/bFGF 2d T3 1d}

siCon siOlig1 siCon siOlig1
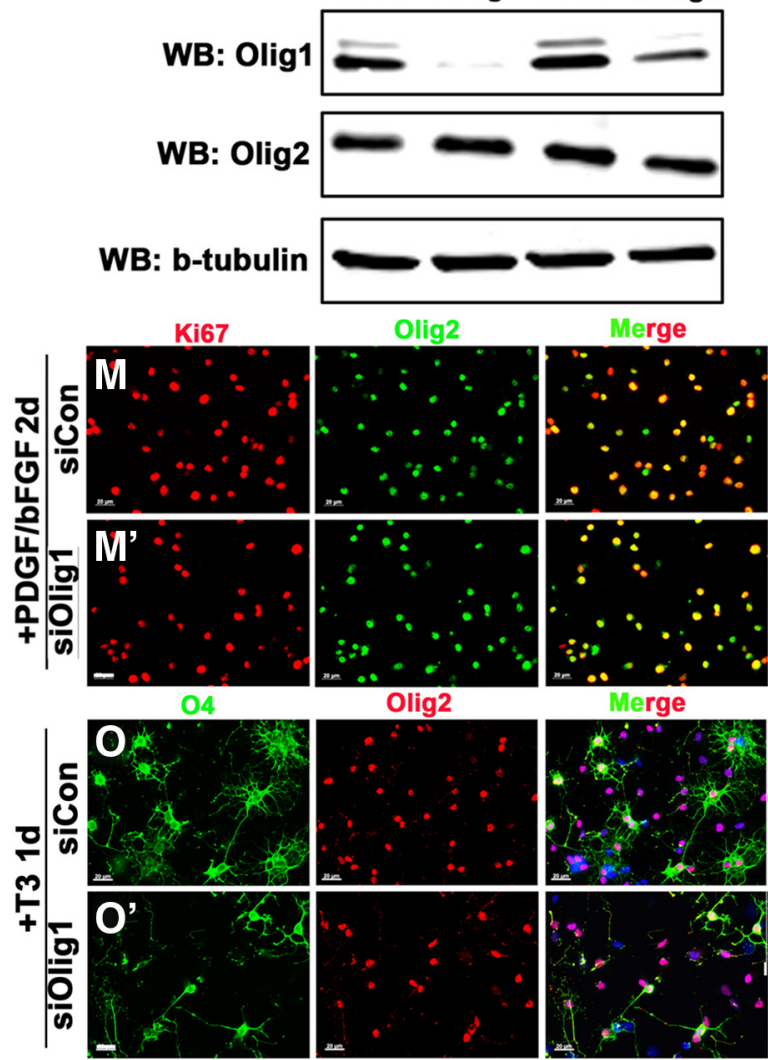
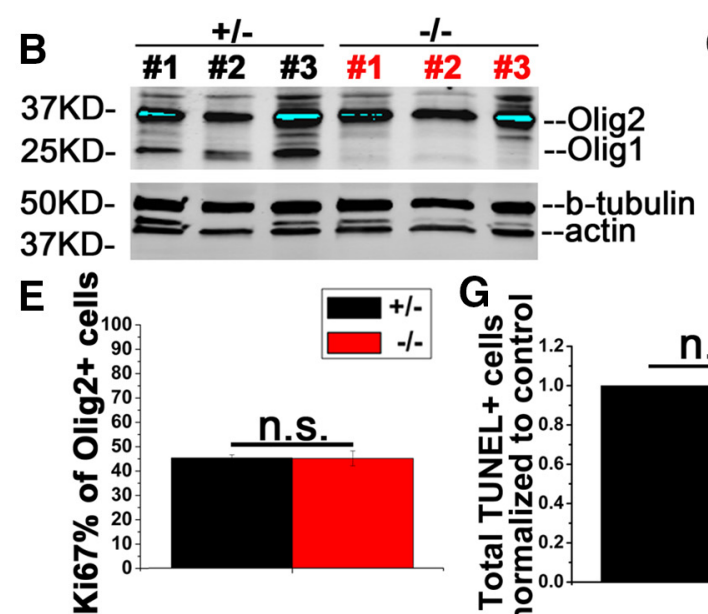

H

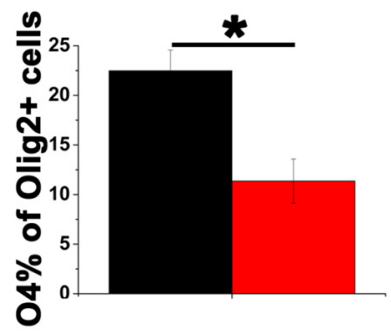

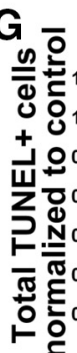

I

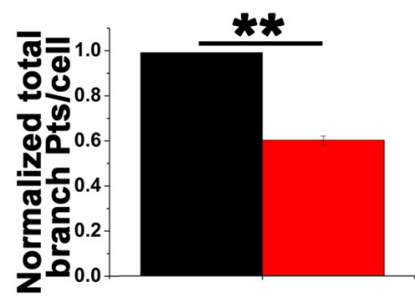

$\mathbf{K}$

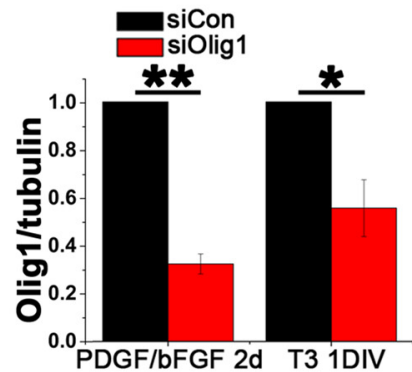

$\mathbf{L}$
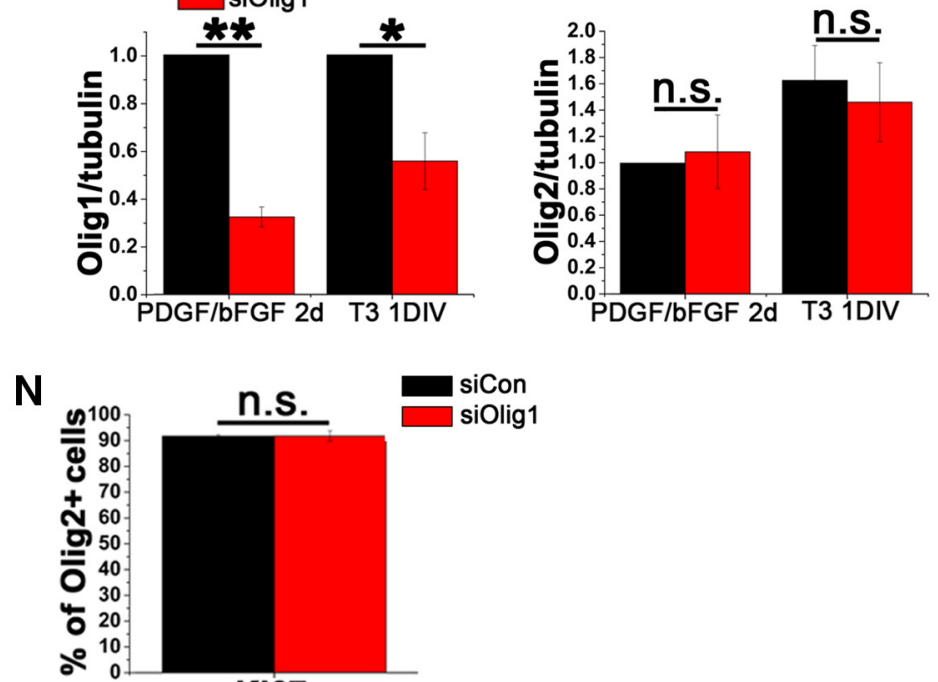

$\mathbf{P}$

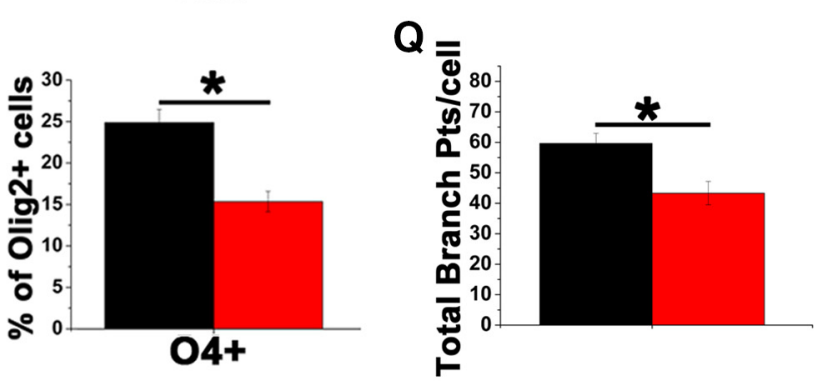

Figure 11. Oligodendrocyte differentiation in the absence of Olig1 in vitro. $A$, Representative images showing absence of 0lig1 in the OPCs derived from neurospheres generated from cortical progenitors of Olig 1 null $\left(\boldsymbol{A}^{\prime}\right)$ versus Olig 1 heterozygous $(\boldsymbol{A})$. Scale bar, $20 \mu \mathrm{m}$. $\boldsymbol{B}$, Representative Western blot of Olig1 and Olig2 protein from cultured OPCs derived as shown in $\boldsymbol{A}$; three blots from each genotype were shown. C, Quantification of the intensity of Western blot bands of 0lig2 protein from lysates of Olig 1 heterozygous (black column) versus Olig 1 null (red column) mice derived OPCs shown in $\boldsymbol{B}$. $\boldsymbol{D}$, Representative images of the cultured Ki67+(red) OPCs derived from Olig1 heterozygous (D) versus Olig1 null ( $\boldsymbol{D}^{\prime}$ ) mice. Scale bar, $20 \mu \mathrm{m}$. $\boldsymbol{E}$, Quantification of the proportion of Ki67+ cells within the 0lig2 + OPC population cultured in proliferation medium for $3 \mathrm{~d}$ in vitro. $\boldsymbol{F}$, Representative images of $04+$ (green) immature oligodendrocytes derived from Olig1 heterozygous $(\boldsymbol{F})$ versus Olig1 null $\left(\boldsymbol{F}^{\prime}\right)$ mice after differentiation $3 \mathrm{~d}$ in vitro. Scale bar, $70 \mu \mathrm{m} . \mathbf{G}-\mathbf{I}$, Quantification of total TUNEL + cells $(\boldsymbol{G})$, the percentage of $04+$ immature oligodendrocytes $(\boldsymbol{H})$, and the total branch points/cell $(\boldsymbol{I})$ as shown in Olig1 heterozygous $(\boldsymbol{F})$ and Olig1 null $\left(\boldsymbol{F}^{\prime}\right) . \boldsymbol{J}$, Immunoblot of 0lig1 and Olig2 expression in OPCs electroporated with (Figure legend continues.) 
of purified OPCs in vitro. OPCs were generated from neurospheres derived from E12.5 to E14.5 cerebrum of Olig1-null or control mice. OPCs were plated and maintained in proliferation medium containing PDGF and FGF for $3 \mathrm{~d}$. In contrast to the in vivo data (Fig. 1), Olig1-null OPCs in vitro had similar proliferation rates to control (Fig. 11D, $D^{\prime}, E$ ), which suggested that Olig1 did not directly regulate the proliferation of OPCs. In contrast with the increased cell death in Olig1-null mice in vivo analysis, the number of apoptotic cells did not increase as OPCs differentiated in the absence of Olig1 in vitro (Fig. 11G).

After switching to differentiation media containing T3 for $3 \mathrm{~d}$ in vitro, $22.5 \%$ of control OPCs differentiated to $\mathrm{O} 4+$ immature oligodendrocytes, but only $11.4 \%$ of Olig1-null OPCs differentiated (Fig. $11 F, F^{\prime}, H$ ). Thus, in culture, these cells had normal proliferation rates, but reduced ability to differentiate, relative to control cells. Olig2 was not upregulated in the cultured oligodendrocytes derived from Olig1-null cerebra (Fig. $11 B, C$ ), which was consistent with the lack of upregulation of Olig2 in Olig1-null cells in cerebrum in vivo (Fig. 10). As in the in vivo context, in the differentiating oligodendrocytes in vitro, Olig1 loss compromised oligodendrocyte morphological differentiation. Analysis of process complexity showed a $40 \%$ reduction of total branch points of Olig1-null O4+ cells compared with control (Fig. 11I).

To confirm that the deficit of OPC differentiation in vitro resulted only from loss of Olig1 and not from unknown compensation during early commitment of the oligodendrocyte lineage in Olig1-null mice, we analyzed rat oligodendrocytes after transient siRNA knockdown of Olig1. These cells are well past the pre-OPC to OPC transition. Acute knockdown of Olig1 in primary rat OPCs derived from postnatal mixed glia was validated by reduction of Olig1 protein after knockdown (Fig. 11J-L). Consistent with the finding from Olig1-null mouse OPCs, knockdown of Olig1 in rat OPCs did not impair their proliferation but had a similar impact on OPC initial differentiation and morphogenesis (Fig. 11M-Q). In summary, consistent with our in vivo findings, Olig1 impacted initial differentiation of cultured rat and mouse OPCs and their subsequent morphological development.

\section{Discussion \\ Developmental phenotypes of different Olig1-null mouse lines}

In this study, we observed the developmental delay and longterm recovery in the spinal cord first reported for this Olig1-null mouse (Lu et al., 2002), but as discussed below, we noted dramatic oligodendrocyte deficits in the brain. The initial report analyzed mice that were still on a mixed genetic background, and in the ensuing 12 years, they have been backcrossed to C57BL/6J, perhaps making the phenotype more robust.

The mild phenotype of the original Olig1-null mice had been speculated to result from compensatory upregulation of Olig2 by

\footnotetext{
$\leftarrow$

(Figure legend continued.) control or Olig1 smart pool siRNAs and cultured as OPCs for $2 \mathrm{~d}$ or shifted to differentiation conditions for $1 \mathrm{~d}$ after $1 \mathrm{~d}$ as $\mathrm{OPCS}$. $\boldsymbol{K}, \boldsymbol{L}$, Quantitative analysis of Olig1 $(\boldsymbol{J})$ or Olig2 (K) protein expression relative to $\beta$-tubulin shown in $\boldsymbol{I}$. $\boldsymbol{M}, \mathbf{0}$, Impact of Olig1 knockdown on OPC proliferation $(\boldsymbol{M})$ and differentiation $(\boldsymbol{0})$. Rat OPCs were electroporated with control $(\boldsymbol{M}, \mathbf{0})$ or Olig 1 siRNAs $\left(\boldsymbol{M}^{\prime}, \mathbf{O}^{\prime}\right)$ cultured in proliferation media for $2 \mathrm{~d}$ and stained with Ki67 (red) and Olig2 (green) $\left(\boldsymbol{M}, \boldsymbol{M}^{\prime}\right)$ or in differentiation media for $1 \mathrm{~d}$ and stained with 04 (green) and 0 lig2 (red) $\left(\mathbf{0}, \mathbf{O}^{\prime}\right)$. Scale bar, $20 \mu \mathrm{m} . \boldsymbol{N}$, Quantitative analysis of the percentage of Ki67+ cells within Olig2 + OPCS. P, Q, Quantitative analysis of the percentage of 04-positive cells $(\boldsymbol{P})$ and the total branch points per cell $(\boldsymbol{Q})$. Data in all graphs represent the mean \pm SEM from three independent experiments; ${ }^{*} p<0.05,{ }^{* *} p<0.005$; paired Student's $t$ test.
}

the cis-acting regulatory effect of the Pgk-Neo cassette retained in the Olig1 locus (Lu et al., 2002), and when that cassette was removed from the original line, the new Olig1-null mice were very severely affected, dying approximately the third postnatal week with severe dysmyelination (Xin et al., 2005). Unfortunately, Olig2 expression was not directly examined in the earlier reports on these lines, so it was unclear whether that explained the difference in phenotype.

One recent study attempted to resolve the discrepancy of these two early Olig1-null mouse lines by generating two new Olig1null mouse lines (Paes de Faria et al., 2014). As in the initial study, much analysis was done in the spinal cord of these two new lines, and developmental delay and subsequent recovery of oligodendrocyte differentiation was observed in spinal cord for both new lines. In neither line was compensation by Olig2 noted (Paes de Faria et al., 2014). These differences among studies have led to significant speculation on the role of Olig1. Paes de Faria et al. (2014) discuss potential reasons for the dramatic differences of the Xin et al. (2005) study relative to the original Lu et al. (2002) and Paes de Faria et al. (2014), but clearly in several Olig1-null lines, spinal cord myelination is delayed but not permanently changed.

Our studies in spinal cord are consistent with these earlier studies on spinal cord development in the absence of Olig1. Nevertheless, despite apparently normal myelination in the spinal cord of Olig1-null mice, our studies do demonstrate that oligodendrocyte production and differentiation were also impaired in spinal cord. However, despite this loss of oligodendrocytes, there was no reduction in Olig2 expression (Fig. 10), which suggested upregulation of Olig2 on a per cell basis in spinal cord. The compensatory upregulation of Olig2 may explain some aspects of the relatively normal myelination in the spinal cord of Olig1-null mice.

\section{Temporospatial control of OPC differentiation by Olig1 in brain}

Oligodendrocyte lineage progression and myelin initiation are tightly controlled both temporally and spatially in the developing mouse brain (Trapp et al., 1997; Baumann and Pham-Dinh, 2001). Both extrinsic and intrinsic cues play critical roles in oligodendrocyte differentiation and myelination (Emery, 2010b; Wood et al., 2013). Olig1 and Olig2 play critical roles in oligodendrocyte specification (Lu et al., 2002; Zhou and Anderson, 2002; Silbereis et al., 2014) and early OPC differentiation (Mei et al., 2013). Silbereis et al. (2014) demonstrated that early commitment to the oligodendrocyte lineage relative to interneuron lineage is regulated by Olig1. Furthermore, within the oligodendrocyte lineage, the current studies show that Olig1 is critical for OPC cell cycle exit and subsequent differentiation of OPCs into premyelinating oligodendrocytes in cerebrum, but not spinal cord.

The pre-OPC to OPC transition has largely been studied in vitro in studies generating oligodendrocytes from human embryonic stem cells or iPS cells (Hu et al., 2009a; Wang et al., 2013). Pre-OPCs express Sox 2 and Sox9 transcription factors, and the transition to OPCs involves Sox10, which is required for maintaining the differentiated state of neural progenitors by repressing the expression of Sox 2 and Sox9 (Castelo-Branco et al., 2014). Based on the known interaction of Olig1 and Sox10 (Li et al., 2007), Olig1 may promote the pre-OPC to OPC commitment by interacting with Sox10 to repress Sox 2 expression in newly formed OPCs, because the Sox2 level remains high in OPCs from Olig1-null mice, in contrast to the sharp downregulation of Sox2 in OPCs from control mice. 
Considering the large set of common target genes downstream of Olig1 and Olig2, including most major myelin protein (Meijer et al., 2012; Weng et al., 2012) and key regulators of differentiation, such as GPR17 (Chen et al., 2009) and Sip1 (Weng et al., 2012), Olig1 and Olig2 may coordinate to regulate early OPC differentiation. The similar phenotype observed in this Olig1-null mice and the Olig2 conditional knock-out mice, in which Olig2 is selectively deleted in OPCs (Mei et al., 2013), implies the potential interplay of these two related transcription factors, which may function simultaneously in OPC differentiation in the developing mouse brain. However, in cerebrum, it appears that neither protein can fully compensate for the loss of the other protein. Although Olig2 has been shown to promote pre-OPC to OPC commitment in vitro (Hu et al., 2009b), this process was impaired in Olig1-null mice, even in the presence of Olig2.

\section{Region-specific regulation of oligodendrocyte differentiation and myelination by Olig1 in the CNS}

Both regional oligodendrocyte heterogeneity and diverse local environmental cues have been suggested to result in different myelination patterns in different CNS regions (Almeida et al., 2011; Vigano et al., 2013). Indeed, regional differences in dysmyelination have been seen in several knock-out mice lines, including conditional Fyn knock-out mice (Sperber et al., 2001), PDGFR $\alpha$ knock-out mice (Fruttiger et al., 1999), and mTOR, Rictor, or Raptor knock-out mice (Bercury et al., 2014; Wahl et al., 2014). The current studies are consistent with these reports. Thus, in contrast to the mild phenotype in the Olig1-null spinal cord, we observed a severe phenotype without long-term recovery in the brain of Olig1-null mice. Despite the increased proliferation of OPCs in Olig1-null mice, there was a permanent deficit of oligodendrocyte number, maturation, and myelination in Olig1-null cerebrum, which lasted through adulthood. It is likely that distinct local environmental cues result in the dramatic myelin deficit in the brain of Olig1-null mice but not in the spinal cord. Whether this difference results simply from the lack of compensatory upregulation of Olig2 in the brain or from other aspects of Olig1 function that lead to the severe reduction of myelinating oligodendrocytes is unclear at this point.

\section{Importance of the subcellular localization of Olig1 in oligodendrocytes}

In contrast to the constant expression and nuclear localization of Olig2 throughout oligodendrocyte development, dynamic expression and subcellular translocation of Olig1 was found to be highly coordinated with oligodendrocyte lineage progression and myelination initiation. Intriguingly, in contrast to the positive role of nuclear Olig1 in early OPC differentiation, Olig1 was downregulated in premyelinating oligodendrocytes before they started ensheathing axons. Olig1 then reappeared in the cytoplasmic of myelinating oligodendrocytes as the myelin segments elongated. The downregulation of Olig1 in premyelinating oligodendrocytes before initiating axon contact suggests that sustained nuclear Olig1 might play an inhibitory role in this process. However, the link between Olig1 subcellular location and function is not clear. As a transcription factor, nuclear Olig1 location in the OPCs fits its role as a positive regulator of early OPC differentiation. However, although fewer in number, Olig1-null oligodendrocytes can generate apparently normal myelin (Figs. 3, $4,6)$. If the cytoplasmic Olig1 does have de novo function in myelinogenesis per se, one might predict that myelinating oligodendrocytes in Olig1-null mice either produce less myelin seg- ments or bear thinner myelin. In contrast to this prediction, in the neocortex of P8 mice when the growing myelin segments can be distinguished, there was no apparent difference between the number of segments generated by individual myelinating oligodendrocytes of Olig1-null and heterozygous mice (Fig. $3 L, M$ ). In addition, the myelin thickness assessed by $g$-ratio was normal in the Olig1-null mice (Fig. 6C,D). Thus, these data do not support a requirement for cytoplasmic Olig1 in myelination. There may be an active function for Olig1 in the cytoplasm, but an interesting alternative explanation could be to prevent Olig1 entry into the nucleus during myelinogenesis, yet maintain it as a store potentially available for remyelination.

\section{Unique function of Olig1 in myelination and remyelination}

Although Olig1 loss apparently can be partially compensated for during developmental myelination, its function is essential for remyelination (Arnett et al., 2004; Whitman et al., 2012). The differentiation block in demyelinated lesions of adult Olig1-null mice resembles MS lesions where OPCs are present but many either fail to differentiate (Chang et al., 2000; Kuhlmann et al., 2008) or are blocked as premyelinating oligodendrocytes unable to differentiate further (Chang et al., 2002). Considering the role of Olig1 in both early OPC differentiation and myelination onset, it is plausible that dysregulation of Olig1 expression and localization may result in the differentiation block of OPCs and premyelinating oligodendrocytes in chronic inactive MS lesions. The current study demonstrates the critical role of Olig1 in oligodendrocyte differentiation in the brain, in parallel with the role of Olig2 in this process. In addition, phosphorylation has been shown to modify the function of both Olig1 and Olig2 in oligodendrocyte maturation and specification respectively ( $\mathrm{Li}$ et al., 2011; Niu et al., 2012). Ongoing studies in this laboratory suggest that post-translational modification may also modulate Olig1 stability and localization. With further mechanistic insight into the regulation of Olig1 function during development, it may be possible to modulate Olig1 expression and activity to promote oligodendrocyte differentiation and subsequent myelination in MS patients.

\section{References}

Almeida RG, Czopka T, Ffrench-Constant C, Lyons DA (2011) Individual axons regulate the myelinating potential of single oligodendrocytes in vivo. Development 138:4443-4450. CrossRef Medline

Arnett HA, Fancy SP, Alberta JA, Zhao C, Plant SR, Kaing S, Raine CS, Rowitch DH, Franklin RJ, Stiles CD (2004) bHLH transcription factor Olig1 is required to repair demyelinated lesions in the CNS. Science 306: 2111-2115. CrossRef Medline

Baumann N, Pham-Dinh D (2001) Biology of oligodendrocyte and myelin in the mammalian central nervous system. Physiol Rev 81:871-927. Medline

Bercury KK, Dai J, Sachs HH, Ahrendsen JT, Wood TL, Macklin WB (2014) Conditional ablation of raptor or rictor has differential impact on oligodendrocyte differentiation and CNS myelination. J Neurosci 34:44664480. CrossRef Medline

Bullock TH, Moore JK, Fields RD (1984) Evolution of myelin sheaths: both lamprey and hagfish lack myelin. Neurosci Lett 48:145-148. CrossRef Medline

Burgess A, Vigneron S, Brioudes E, Labbé JC, Lorca T, Castro A (2010) Loss of human Greatwall results in G2 arrest and multiple mitotic defects due to deregulation of the cyclin B-Cdc2/PP2A balance. Proc Natl Acad Sci U S A 107:12564-12569. CrossRef Medline

Castedo M, Perfettini JL, Roumier T, Andreau K, Medema R, Kroemer G (2004) Cell death by mitotic catastrophe: a molecular definition. Oncogene 23:2825-2837. CrossRef Medline

Castelo-Branco G, Lilja T, Wallenborg K, Falcão AM, Marques SC, Gracias A, Solum D, Paap R, Walfridsson J, Teixeira AI, Rosenfeld MG, Jepsen K, 
Hermanson O (2014) Neural stem cell differentiation is dictated by distinct actions of nuclear receptor corepressors and histone deacetylases. Stem Cell Reports 3:502-515. CrossRef Medline

Chang A, Nishiyama A, Peterson J, Prineas J, Trapp BD (2000) NG2positive oligodendrocyte progenitor cells in adult human brain and multiple sclerosis lesions. J Neurosci 20:6404-6412. Medline

Chang A, Tourtellotte WW, Rudick R, Trapp BD (2002) Premyelinating oligodendrocytes in chronic lesions of multiple sclerosis. N Engl J Med 346:165-173. CrossRef Medline

Chen Y, Wu H, Wang S, Koito H, Li J, Ye F, Hoang J, Escobar SS, Gow A, Arnett HA, Trapp BD, Karandikar NJ, Hsieh J, Lu QR (2009) The oligodendrocyte-specific G protein-coupled receptor GPR17 is a cellintrinsic timer of myelination. Nat Neurosci 12:1398-1406. CrossRef Medline

Dai J, Bercury KK, Macklin WB (2014) Interaction of mTOR and Erk1/2 signaling to regulate oligodendrocyte differentiation. Glia 62:2096-2109. CrossRef Medline

Ellis P, Fagan BM, Magness ST, Hutton S, Taranova O, Hayashi S, McMahon A, Rao M, Pevny L (2004) SOX2, a persistent marker for multipotential neural stem cells derived from embryonic stem cells, the embryo or the adult. Dev Neurosci 26:148-165. CrossRef Medline

Emery B (2010a) Regulation of oligodendrocyte differentiation and myelination. Science 330:779-782. CrossRef Medline

Emery B (2010b) Transcriptional and post-transcriptional control of CNS myelination. Curr Opin Neurobiol 20:601-607. CrossRef Medline

Franklin RJ, Ffrench-Constant C (2008) Remyelination in the CNS: from biology to therapy. Nat Rev Neurosci 9:839-855. CrossRef Medline

Fruttiger M, Karlsson L, Hall AC, Abramsson A, Calver AR, Boström H, Willetts K, Bertold CH, Heath JK, Betsholtz C, Richardson WD (1999) Defective oligodendrocyte development and severe hypomyelination in PDGF-A knock-out mice. Development 126:457-467. Medline

Hildebrand C, Remahl S, Persson H, Bjartmar C (1993) Myelinated nerve fibres in the CNS. Prog Neurobiol 40:319-384. CrossRef Medline

Hu BY, Du ZW, Zhang SC (2009a) Differentiation of human oligodendrocytes from pluripotent stem cells. Nat Protoc 4:1614-1622. CrossRef Medline

Hu BY, Du ZW, Li XJ, Ayala M, Zhang SC (2009b) Human oligodendrocytes from embryonic stem cells: conserved SHH signaling networks and divergent FGF effects. Development 136:1443-1452. CrossRef Medline

Kee N, Sivalingam S, Boonstra R, Wojtowicz JM (2002) The utility of Ki-67 and BrdU as proliferative markers of adult neurogenesis. J Neurosci Methods 115:97-105. CrossRef Medline

Kuhlmann T, Miron V, Cuo Q, Wegner C, Antel J, Brück W (2008) Differentiation block of oligodendroglial progenitor cells as a cause for remyelination failure in chronic multiple sclerosis. Brain 131:1749-1758. CrossRef Medline

Li H, Lu Y, Smith HK, Richardson WD (2007) Olig1 and Sox10 interact synergistically to drive myelin basic protein transcription in oligodendrocytes. J Neurosci 27:14375-14382. CrossRef Medline

Li H, de Faria JP, Andrew P, Nitarska J, Richardson WD (2011) Phosphorylation regulates OLIG2 cofactor choice and the motor neuronoligodendrocyte fate switch. Neuron 69:918-929. CrossRef Medline

Lu QR, Sun T, Zhu Z, Ma N, Garcia M, Stiles CD, Rowitch DH (2002) Common developmental requirement for Olig function indicates a motor neuron/oligodendrocyte connection. Cell 109:75-86. CrossRef Medline

Mei F, Wang H, Liu S, Niu J, Wang L, He Y, Etxeberria A, Chan JR, Xiao L (2013) Stage-specific deletion of Olig2 conveys opposing functions on differentiation and maturation of oligodendrocytes. J Neurosci 33:84548462. CrossRef Medline

Meijer DH, Kane MF, Mehta S, Liu H, Harrington E, Taylor CM, Stiles CD, Rowitch DH (2012) Separated at birth? The functional and molecular divergence of OLIG1 and OLIG2. Nat Rev Neurosci 13:819-831. CrossRef Medline
Menn B, Garcia-Verdugo JM, Yaschine C, Gonzalez-Perez O, Rowitch D, Alvarez-Buylla A (2006) Origin of oligodendrocytes in the subventricular zone of the adult brain. J Neurosci 26:7907-7918. CrossRef Medline

Nave KA (2010) Myelination and the trophic support of long axons. Nat Rev Neurosci 11:275-283. CrossRef Medline

Niu J, Mei F, Wang L, Liu S, Tian Y, Mo W, Li H, Lu QR, Xiao L (2012) Phosphorylated olig1 localizes to the cytosol of oligodendrocytes and promotes membrane expansion and maturation. Glia 60:1427-1436. CrossRef Medline

Paes de Faria J, Kessaris N, Andrew P, Richardson WD, Li H (2014) New Olig1-null mice confirm a non-essential role for Olig1 in oligodendrocyte development. BMC Neurosci 15:12. CrossRef Medline

Pedraza CE, Monk R, Lei J, Hao Q, Macklin WB (2008) Production, characterization, and efficient transfection of highly pure oligodendrocyte precursor cultures from mouse embryonic neural progenitors. Glia 56: 1339-1352. CrossRef Medline

Reid S, Ritchie A, Boring L, Gosling J, Cooper S, Hangoc G, Charo IF, Broxmeyer HE (1999) Enhanced myeloid progenitor cell cycling and apoptosis in mice lacking the chemokine receptor, CCR2. Blood 93:15241533. Medline

Silbereis JC, Nobuta H, Tsai HH, Heine VM, McKinsey GL, Meijer DH, Howard MA, Petryniak MA, Potter GB, Alberta JA, Baraban SC, Stiles CD, Rubenstein JL, Rowitch DH (2014) Olig1 function is required to repress $\mathrm{dlx} 1 / 2$ and interneuron production in mammalian brain. Neuron 81:574-587. CrossRef Medline

Sperber BR, Boyle-Walsh EA, Engleka MJ, Gadue P, Peterson AC, Stein PL, Scherer SS, McMorris FA (2001) A unique role for Fyn in CNS myelination. J Neurosci 21:2039-2047. Medline

Trapp BD, Nishiyama A, Cheng D, Macklin W (1997) Differentiation and death of premyelinating oligodendrocytes in developing rodent brain. J Cell Biol 137:459-468. CrossRef Medline

Viganò F, Möbius W, Götz M, Dimou L (2013) Transplantation reveals regional differences in oligodendrocyte differentiation in the adult brain. Nat Neurosci 16:1370-1372. CrossRef Medline

Wahl SE, McLane LE, Bercury KK, Macklin WB, Wood TL (2014) Mammalian target of rapamycin promotes oligodendrocyte differentiation, initiation and extent of CNS myelination. J Neurosci 34:4453-4465. CrossRef Medline

Wang S, Bates J, Li X, Schanz S, Chandler-Militello D, Levine C, Maherali N, Studer L, Hochedlinger K, Windrem M, Goldman SA (2013) Human iPSC-derived oligodendrocyte progenitor cells can myelinate and rescue a mouse model of congenital hypomyelination. Cell Stem Cell 12:252-264. CrossRef Medline

Weng Q, Chen Y, Wang H, Xu X, Yang B, He Q, Shou W, Chen Y, Higashi Y, van den Berghe V, Seuntjens E, Kernie SG, Bukshpun P, Sherr EH, Huylebroeck D, Lu QR (2012) Dual-mode modulation of Smad signaling by Smad-interacting protein Sip1 is required for myelination in the central nervous system. Neuron 73:713-728. CrossRef Medline

Whitman LM, Blanc CA, Schaumburg CS, Rowitch DH, Lane TE (2012) Oligl function is required for remyelination potential of transplanted neural progenitor cells in a model of viral-induced demyelination. Exp Neurol 235:380-387. CrossRef Medline

Wood TL, Bercury KK, Cifelli SE, Mursch LE, Min J, Dai J, Macklin WB (2013) mTOR: a link from the extracellular milieu to transcriptional regulation of oligodendrocyte development. ASN Neuro 5:e00108. CrossRef Medline

Xin M, Yue T, Ma Z, Wu FF, Gow A, Lu QR (2005) Myelinogenesis and axonal recognition by oligodendrocytes in brain are uncoupled in Olig1null mice. J Neurosci 25:1354-1365. CrossRef Medline

Zhou Q, Anderson DJ (2002) The bHLH transcription factors OLIG2 and OLIG1 couple neuronal and glial subtype specification. Cell 109:61-73. CrossRef Medline 